\title{
Catalysis Today \\ Individual amounts of Lewis and Brønsted acid sites on metal oxides from NH3 adsorption equilibrium: Case of TiO2 based solids \\ --Manuscript Draft--
}

\begin{tabular}{|c|c|}
\hline Manuscript Number: & CATTOD-D-20-00073R1 \\
\hline Article Type: & SI: 60th anniversary of IRC \\
\hline Keywords: & V2O5/WO3/TiO2; ammonia adsorption; amount of acid sites; NH3-SCR; active site. \\
\hline Corresponding Author: & $\begin{array}{l}\text { Daniel Bianchi, PhD } \\
\text { University of Lyon } \\
\text { Villeurbanne, FRANCE }\end{array}$ \\
\hline First Author: & Daniel Bianchi, PhD \\
\hline \multirow[t]{8}{*}{ Order of Authors: } & Daniel Bianchi, PhD \\
\hline & François Giraud, Ph. D \\
\hline & Christophe Geantet, Dr \\
\hline & Nolven Guillaume, CR \\
\hline & Stéphane Loridant, Dr \\
\hline & Sebastien Gros, Ph D \\
\hline & Lynda Porcheron, Ph D \\
\hline & Mohamed Kanniche, Ph D \\
\hline Abstract: & 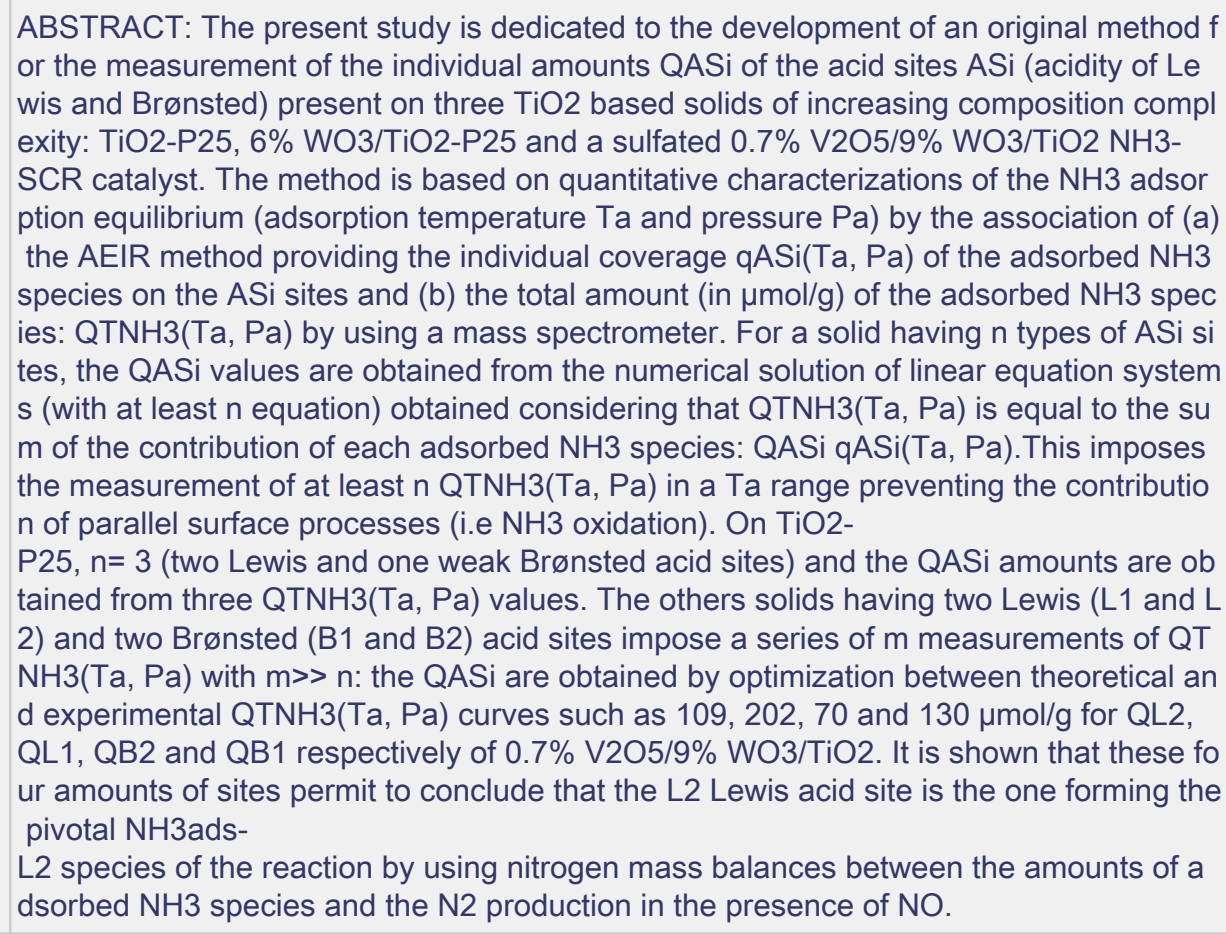 \\
\hline
\end{tabular}




\section{Highlights}

- The individual amounts of acid sites on metal oxides are measured using $\mathrm{NH}_{3}$ adsorption equilibrium conditions.

- The original method is based on the association of quantitative FTIR spectroscopy and volumetric measurements.

- The method is applied to $\mathrm{TiO}_{2}, \mathrm{WO}_{3} / \mathrm{TiO}_{2}$ and a $\mathrm{V}_{2} \mathrm{O}_{5} / \mathrm{WO}_{3} / \mathrm{TiO}_{2} \mathrm{NH}_{3}-\mathrm{SCR}$ catalyst.

- The measurements permit the identification of the active acid site of $\mathrm{V}_{2} \mathrm{O}_{5} / \mathrm{WO}_{3} / \mathrm{TiO}_{2}$ for the $\mathrm{NH}_{3}-\mathrm{SCR}$ reaction. 


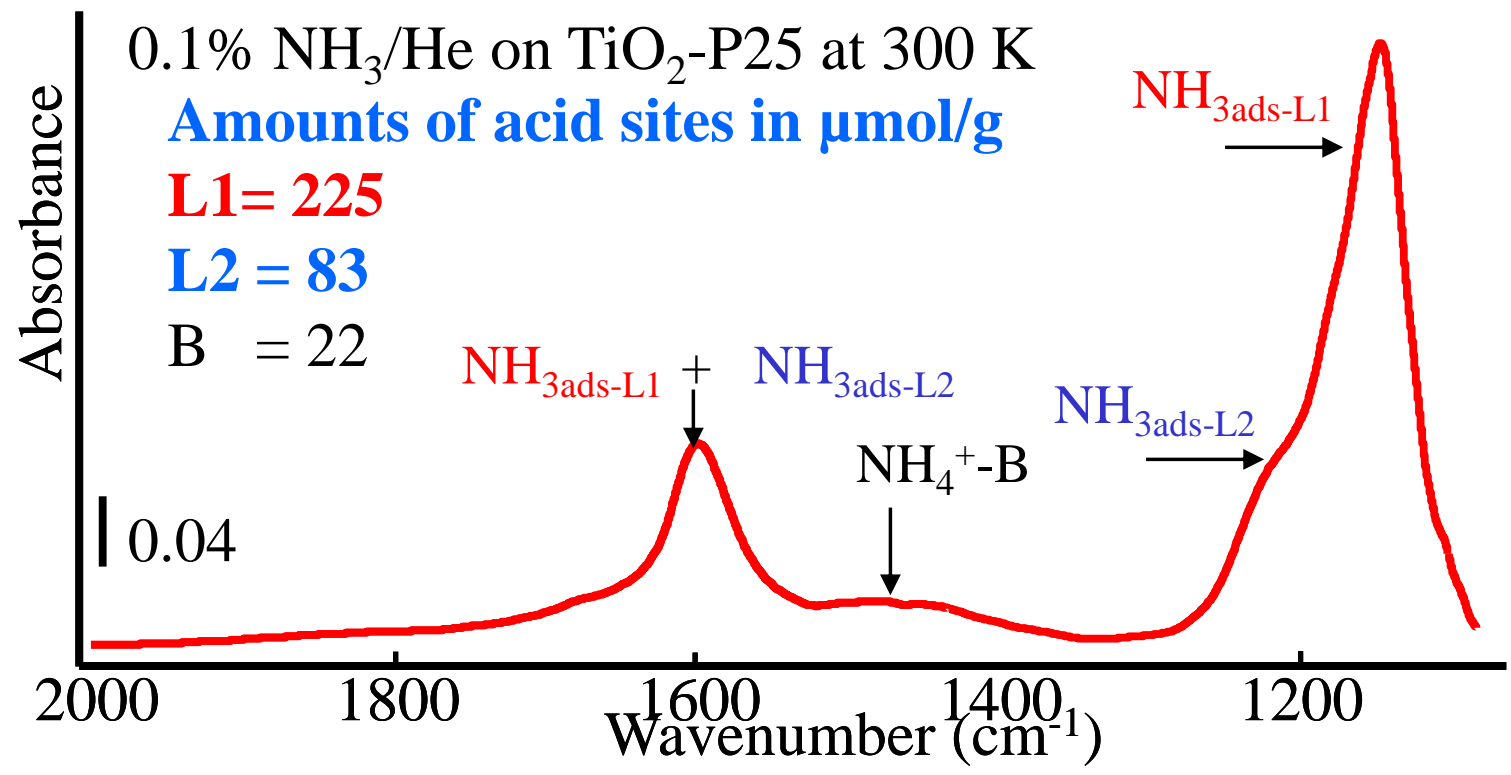

Graphical Abstract 


\title{
Individual amounts of Lewis and Brønsted acid sites on
} metal oxides from $\mathrm{NH}_{3}$ adsorption equilibrium: Case of

\section{$\mathrm{TiO}_{2}$ based solids}

\begin{abstract}
AUTHOR NAMES
François Giraud, ${ }^{1,2}$ Christophe Geantet, ${ }^{1}$ Nolven Guilhaume, ${ }^{1}$ Stéphane Loridant, ${ }^{1}$ Sébastien Gros, ${ }^{2}$ Lynda Porcheron, ${ }^{2}$ Mohamed Kanniche, ${ }^{2}$ and Daniel Bianchi ${ }^{1 *}$
\end{abstract}

\section{AUTHOR ADDRESS}

${ }^{1}$ Université de Lyon, Université Claude Bernard Lyon I, Institut de Recherche sur la Catalyse et l'Environnement de Lyon (IRCELYON), UMR 5256 CNRS, 43 Boulevard du 11 Novembre 1918, 69622 Villeurbanne-France.

${ }^{2}$ EDF- Fluid Dynamics, Power Generation and Environment Department, 6 Quai Watier, 78401, Chatou-France. 
ABSTRACT: The present study is dedicated to the development of an original method for the measurement of the individual amounts $\mathrm{Q}_{\mathrm{ASi}}$ of the acid sites $\mathrm{AS}_{\mathrm{i}}$ (acidity of Lewis and Brønsted) present on three $\mathrm{TiO}_{2}$ based solids of increasing composition complexity: $\mathrm{TiO}_{2}-\mathrm{P} 25$, $6 \% \mathrm{WO}_{3} / \mathrm{TiO}_{2}-\mathrm{P} 25$ and a sulfated $0.7 \% \mathrm{~V}_{2} \mathrm{O}_{5} / 9 \% \mathrm{WO}_{3} / \mathrm{TiO}_{2} \mathrm{NH}_{3}-\mathrm{SCR}$ catalyst. The method is based on quantitative characterizations of the $\mathrm{NH}_{3}$ adsorption equilibrium (adsorption temperature $T_{a}$ and pressure $P_{a}$ ) by the association of (a) the AEIR method providing the individual coverage $\theta_{\mathrm{ASi}}\left(\mathrm{T}_{\mathrm{a}}, \mathrm{P}_{\mathrm{a}}\right)$ of the adsorbed $\mathrm{NH}_{3}$ species on the $\mathrm{AS}_{\mathrm{i}}$ sites and (b) the total amount (in $\mu \mathrm{mol} / \mathrm{g}$ ) of the adsorbed $\mathrm{NH}_{3}$ species: $\mathrm{QTNH}\left(\mathrm{T}_{\mathrm{a}}, \mathrm{P}_{\mathrm{a}}\right)$ by using a mass spectrometer. For a solid having $\mathrm{n}$ types of $\mathrm{AS}_{\mathrm{i}}$ sites, the $\mathrm{Q}_{\mathrm{ASi}}$ values are obtained from the numerical solution of linear equation systems (with at least $\mathrm{n}$ equation) obtained considering that $\mathrm{QTNH}_{3}\left(\mathrm{~T}_{\mathrm{a}}, \mathrm{P}_{\mathrm{a}}\right)$ is equal to the sum of the contribution of each adsorbed $\mathrm{NH}_{3}$ species: $\mathrm{QASi} \theta_{A S i}\left(T_{a}, P_{a}\right)$.This imposes the measurement of at least $n \mathrm{QTNH}_{3}\left(\mathrm{~T}_{\mathrm{a}}, \mathrm{P}_{\mathrm{a}}\right)$ in a $\mathrm{T}_{\mathrm{a}}$ range preventing the contribution of parallel surface processes (i.e $\mathrm{NH}_{3}$ oxidation). On $\mathrm{TiO}_{2}-\mathrm{P} 25, \mathrm{n}=3$ (two Lewis and one weak Brønsted acid sites) and the $\mathrm{Q}_{\mathrm{ASi}}$ amounts are obtained from three $\mathrm{QTNH}_{3}\left(\mathrm{~T}_{\mathrm{a}}, \mathrm{P}_{\mathrm{a}}\right)$ values. The others solids having two Lewis (L1 and L2) and two Brønsted (B1 and B2) acid sites impose a series of $m$ measurements of $\mathrm{QTNH}_{3}\left(\mathrm{~T}_{\mathrm{a}}, \mathrm{P}_{\mathrm{a}}\right)$ with $\mathrm{m}>>\mathrm{n}$ : the $\mathrm{Q}_{\mathrm{ASi}}$ are obtained by optimization between theoretical and experimental $\mathrm{QTNH}_{3}\left(\mathrm{~T}_{\mathrm{a}}, \mathrm{P}_{\mathrm{a}}\right)$ curves such as 109, 202, 70 and 130 $\mu \mathrm{mol} / \mathrm{g}$ for $\mathrm{Q}_{\mathrm{L} 2}, \mathrm{Q}_{\mathrm{L} 1}, \mathrm{Q}_{\mathrm{B} 2}$ and $\mathrm{Q}_{\mathrm{B} 1}$ respectively of $0.7 \% \mathrm{~V}_{2} \mathrm{O}_{5} / 9 \% \mathrm{WO}_{3} / \mathrm{TiO}_{2}$. It is shown that these four amounts of sites permit to conclude that the L2 Lewis acid site is the one forming the pivotal $\mathrm{NH}_{3 \text { ads-L2 }}$ species of the reaction by using nitrogen mass balances between the amounts of adsorbed $\mathrm{NH}_{3}$ species and the $\mathrm{N}_{2}$ production in the presence of $\mathrm{NO}$.

Keywords: $\mathrm{V}_{2} \mathrm{O}_{5} / \mathrm{WO}_{3} / \mathrm{TiO}_{2}$, ammonia adsorption, amount of acid sites, $\mathrm{NH}_{3}$-SCR, active site. 


\section{Introduction}

The flue gas denitrification in coal-fired power plants $[1,2]$ by the reduction of $\mathrm{NO}_{\mathrm{x}}$ with $\mathrm{NH}_{3}$ in the presence of $\mathrm{O}_{2}$ (named $\mathrm{NH}_{3}-\mathrm{SCR}$ ) on $\mathrm{V}_{2} \mathrm{O}_{5} / \mathrm{WO}_{3} / \mathrm{TiO}_{2}$ catalysts [1-4] is one of the industrial processes using a catalytic reaction performed on the acid sites on metal oxides [5]. It is known that that a number of Lewis (named LAS) and Brønsted (named BAS) acid sites can be present on the surface of dispersed metal oxides due to different (a) unsaturated cations $\mathrm{M}_{\mathrm{i}}^{+\delta}$ [6] and (b) hydroxyl groups $\mathrm{OH}_{\mathrm{i}}$ able to provide a proton [7] respectively. The present study is dedicated to the development of an analytical method for the quantification of the individual amounts of the different LAS and BAS sites on metal oxides. Then these data are used to identify the active sites of a $\mathrm{V}_{2} \mathrm{O}_{5} / \mathrm{WO}_{3} / \mathrm{TiO}_{2} \mathrm{NH}_{3}-\mathrm{SCR}$ catalyst.

The identification of the acid sites of metal oxides is realized via the adsorption of probe base molecules such as $\mathrm{CO}$, nitriles, $\mathrm{NH}_{3}$ and amines implying that the experimental data are dependent on the properties of the sites and the probe molecule $[6,7]$. Consequently, working on the relationships between acid sites and a catalytic reaction, it is recommended using the reactant as probe molecule [6] such as $\mathrm{NH}_{3}$ in the present study considering the $\mathrm{NH}_{3}-\mathrm{SCR}$ reaction. FTIR spectroscopy is of particular interest for the study of the adsorbed species formed by the probe molecules as detailed in a number of review articles $[6,8,9]$ and references therein). For the adsorption of $\mathrm{NH}_{3}$, the presence of LAS and/or BAS is revealed by the symmetric $\left(\delta_{\mathrm{s}}\right)$ and asymmetric $\left(\delta_{\mathrm{as}}\right)$ deformation IR bands of the $\mathrm{NH}_{3 \text { ads- }}$ and $\mathrm{NH}_{4}{ }^{+}$species in the $1700-1100 \mathrm{~cm}^{-1}$ range [8-13]. The position of the $\delta_{\mathrm{s}}$ IR band of $\mathrm{NH}_{3 \text { ads-L }}$ species is strongly sensitive to the nature of the LAS and the detection of more than one IR band in the range 1250-1100 $\mathrm{cm}^{-1}$ was ascribed to different LAS such as two on $\mathrm{TiO}_{2}$ solids [10-13].

FTIR spectroscopy can be used for the quantification of the amounts of LAS and BAS adsorbing $\mathrm{NH}_{3}$ via the Beer-Lambert law after the measurement of the intensities (in

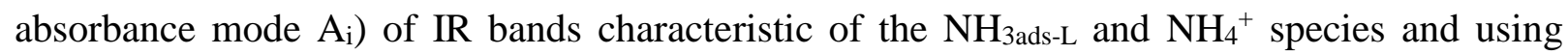


extinction coefficients from literature. However, this parameter is dependent on the solid composition, the experimental conditions and the environment of the adsorbed species $[6,14]$ leading to significant differences in literature data such as for the extinction coefficient (in $\mathrm{cm}$ $\mu \mathrm{mol}^{-1}$ ) of the IR band of the $\mathrm{NH}_{4}{ }^{+}$species at $\approx 1450 \mathrm{~cm}^{-1}: 13 \pm 0.3$ [15], $9.4 \pm 0.7$ [16] and 3.03 [17]. This explains the interest for temperature programmed desorption methods (TPD) $[18,19]$ which may differentiate the adsorbed $\mathrm{NH}_{3}$ species formed at $300 \mathrm{~K}$ according to their activation energy of desorption. The differences in their either true (TPD without readsorption) or net (TPD with readsorption) rates of desorption measured with a mass spectrometer (MS) during the linear increase in the temperature in an inert gas lead to different peaks of $\mathrm{NH}_{3}$ production. These peaks are characterized by the temperature $T_{M}$ of their maximum: the higher is $E_{d}$, the higher is $T_{M}$ and the stronger is the strength of the site. The amount of $\mathrm{NH}_{3}$ produced in each peak should be related to the amounts of the different acid sites. However an accurate quantification is rarely allowed because the TPD peaks generally overlap as for the $\mathrm{NH}_{3}-\mathrm{TPD}$ on $\mathrm{V}_{2} \mathrm{O}_{5}-\mathrm{WO}_{3}-\mathrm{TiO}_{2}$ catalysts [20-28]. This is due to (a) the presence of $\mathrm{NH}_{3}$ ads-L and $\mathrm{NH}_{4}{ }^{+}$ species having activation energies of desorption depending on the coverages $\theta$ : $E_{d}(\theta)$ and (b) the contribution of $\mathrm{NH}_{3}$ readsorption during the TPD which is rarely prevented on conventional catalysts as shown by Demmin and Gorte [29]. For instance, it has been shown that the heat of adsorption of the $\mathrm{NH}_{3 \text { ads-L }}$ species formed on the strongest LAS of a $\mathrm{TiO}_{2}$ solid decrease linearly with the increase in the coverage from $160 \mathrm{~kJ} / \mathrm{mol}$ to $104 \mathrm{~kJ} / \mathrm{mol}$ at low and high coverages respectively [30]. For this species, Fig S1 shows the theoretical changes in its coverage and the rate of $\mathrm{NH}_{3}$ production during TPD experiments without and with $\mathrm{NH}_{3}$ readsorption. For the two situations a very broad peak (extended on $\Delta \mathrm{T}>300 \mathrm{~K}$ ) is observed particularly considering readsorption. Thus if several types of acid sites are present on a solid, this explains that strongly overlapped $\mathrm{NH}_{3}$ peaks are observed preventing their accurate decomposition and so the quantification of the sites. For these situations, $\mathrm{NH}_{3}-\mathrm{TPD}$ data are 
mainly used for the quantification of weak, medium and strong acid sites (whatever their natures) by considering the amount of $\mathrm{NH}_{3}$ desorbed in temperature range such as $\mathrm{T}_{\mathrm{d}}<\approx 473 \mathrm{~K}$, $473 \approx<\mathrm{T}_{\mathrm{d}}<\approx 573$ and $\mathrm{T}_{\mathrm{d}}>\approx 573 \mathrm{~K}$ respectively [25-27]. In some studies, the $\mathrm{NH}_{3}-\mathrm{TPD}$ peak is decomposed into a number of symmetrical peaks (i.e. three in ref [31]). However, without a theoretical support this remains an approximate quantification of the sites. Finally, another difficulty can be associated to $\mathrm{NH}_{3}$-TPD on some metal oxides; the contribution of parallel reactions such as the oxidation of $\mathrm{NH}_{3}$ at high temperatures [20, 21].

Niwa and Katada [14] and references therein have developed an analytical procedure (named IRMS-TPD) to overcome the difficulties associated to TPD methods by the association of FTIR and MS measurements according to operando procedures in experimental conditions leading to free readsorption. IRMS-TPD consists in the simultaneous measurement during the linear increase in the temperature $\left(\mathrm{dT}=\beta \mathrm{dt}\right.$ ) of the net desorption rates of (a) $\mathrm{NH}_{3}$ using a mass spectrometer and (b) $\mathrm{NH}_{3 \text { ads-L }}$ and $\mathrm{NH}_{4}{ }^{+}$species using the decrease in the intensity $\mathrm{A}_{\mathrm{i}}$ of their IR bands according to $-\mathrm{dA}_{\mathrm{i}} / \mathrm{dT}$. Using the coincidence of the $\mathrm{T}_{\mathrm{M}}$ values obtained from the $\mathrm{MS}$ and FTIR data, IRMS-TPD provides the enthalpy and entropy of adsorption of each adsorbed species. Moreover, the amounts of the LAS and BAS can be quantified [32] by assuming that the sum of concentrations of ammonia from all the adsorbed species should be equal to that $\mathrm{C}_{\mathrm{g}}$ measured by MS over the temperature range according to: $\mathrm{C}_{\mathrm{g}}=\sum X_{i}\left(-\frac{d A_{i}}{d t}\right)$ where $\mathrm{X}_{\mathrm{i}}=\alpha \varepsilon_{\mathrm{I}}^{-1}$ and $\alpha$ is a constant depending on the experimental conditions (i.e heating and gas flow rates) and $\varepsilon_{\mathrm{i}}$ is the molar extinction coefficient $\left(\mathrm{cm}^{-1} \mathrm{~m}^{2} \mathrm{~mol}^{-1}\right)$ for the IR band characterizing the adsorbed species $\mathrm{i}\left[32\right.$ ]. Because each $-\mathrm{dA}_{\mathrm{i}} \mathrm{dT}$ have their unique temperature dependency, the set of coefficients $X_{i}$ giving the best fitting between $C_{g}$ and $-\left(\mathrm{dA}_{\mathrm{i}} \mathrm{dT}\right)$ can be obtained by a numerical method (i.e least squares method [32 ]). Then this provides the adsorption coefficient $\varepsilon_{\mathrm{i}}$ for each IR bands and finally the amount of adsorbed $\mathrm{NH}_{3}$ and $\mathrm{NH}_{4}{ }^{+}$species. However, one 
disadvantage of TPD procedures, considering the measurement of the amounts of LAS and BAS, is the isothermal desorption performed before the increase in $\mathrm{T}$ often at $\mathrm{T}_{\mathrm{d}}=373 \mathrm{~K}[16$, 20, 25-28] and for $1 \mathrm{~h}$. The purpose of this procedure is the removal of $\mathrm{NH}_{3}$ physisorbed like species. However, calculations show that this leads to the desorption of a significant fraction of $\mathrm{NH}_{3}$ species formed on strong acid sites. For instance, Fig S2 shows that $\approx 40 \%$ of the $\mathrm{NH}_{3 \text { ads- }}$ species formed on the strongest LAS of a $\mathrm{TiO}_{2}$ solid are desorbed after $1 \mathrm{~h}$ at $\mathrm{T}_{\mathrm{d}}=373 \mathrm{~K}$. This situation explains the interests for the measurement of the individual amounts of acid sites based on procedures using $\mathrm{NH}_{3}$ adsorption equilibrium as developed in the present study.

The present method is an extension of those developed in previous works named adsorption equilibrium infrared spectroscopy (AEIR) $[33,34]$ and temperature programmed adsorption equilibrium (TPAE) [35] using two separate FTIR and MS setups in contrast with IRMS-TPD [14, 32]. It is based on the measurement of the total amounts of $\mathrm{NH}_{3}$ adsorption: $\mathrm{QTNH}_{3}\left(\mathrm{~T}_{\mathrm{a}}, \mathrm{P}_{\mathrm{a}}\right)$ at the adsorption equilibrium for adsorption temperature $\mathrm{T}_{\mathrm{a}}$ and pressure $\mathrm{P}_{\mathrm{a}}$ by using the MS setup. This amount is related to the different acid sites $\mathrm{AS}_{\mathrm{i}}$ according to:

$$
Q T_{N H 3}\left(T_{a}, P_{a}\right)=\sum_{i=1}^{n} Q_{A S i} \quad \theta_{N H 3 a d s-A S i}\left(T_{a}, P_{a}\right)
$$

where: $\mathrm{n}$ is the number of different acid sites $\mathrm{AS}_{\mathrm{i}}\left(\mathrm{LAS}\right.$ and/or BAS), $\mathrm{QASi}_{\mathrm{A}}$ is the amount of the $\mathrm{AS}_{\mathrm{i}}$ sites and $\theta_{N H 3 a d s-A S i}\left(T_{a}, P_{a}\right)$ is the coverage of the adsorbed $\mathrm{NH}_{3 \text { ads-ASi }}$ species (either $\mathrm{NH}_{3 \text { ads-L }}$ or $\mathrm{NH}_{4}^{+}$) on $\mathrm{AS}_{\mathrm{i}}$ at $\mathrm{T}_{\mathrm{a}}$ and $\mathrm{P}_{\mathrm{a}}$. Note that eq (1) concerns the adsorption equilibrium coverage of the adsorbed species whereas IRMS-TPD focus on the net desorption rate $[14,16$, 32]. Equation (1) shows that the $\mathrm{Q}_{\mathrm{ASi}}$ values can be obtained from a $\mathrm{n}$ linear equations system by (a) measuring $\mathrm{QTNH}_{3}\left(\mathrm{~T}_{\mathrm{a}}, \mathrm{P}_{\mathrm{a}}\right)$ and (b) determining the coverages of the $\mathrm{NH}_{3 \text { ads-ASi }}$ species for $\mathrm{n}\left(\mathrm{T}_{\mathrm{a}}, \mathrm{P}_{\mathrm{a}}\right)$ couples. In matrix term the linear equation system is as follows:

$$
\mathrm{QTNH}_{3}=\Theta \times \mathrm{QASI}
$$


where $\mathrm{QTNH}_{3}$ is the column matrix of the $\mathrm{QTNH}_{3}\left(\mathrm{~T}_{\mathrm{a}}, \mathrm{P}_{\mathrm{a}}\right)$ values, $\Theta$ is $\mathrm{n} \times \mathrm{n}$ matrix having as coefficients the coverages of the $\mathrm{n}$ adsorbed $\mathrm{NH}_{3}$ species for $\mathrm{n}$ experimental conditions and QASI is the column matrix of the unknown amounts of each of the $n \mathrm{AS}_{\mathrm{i}}$ sites. The linear equations system can be solved by numerical methods [36]. In these calculations, the coefficients of the $\Theta$ matrix must be known. This has been performed in previous works using the AEIR method for three solids of increasing composition complexity $[30,37,38]$ : a commercial $\mathrm{TiO}_{2}$, its modification by deposition of $\mathrm{WO}_{3}$ and a $\mathrm{V}_{2} \mathrm{O}_{5} / \mathrm{WO}_{3} / \mathrm{TiO}_{2} \mathrm{NH}_{3}-\mathrm{SCR}$ catalyst. From the evolution of the intensity of IR bands ascribed to $\mathrm{NH}_{3 \text { ads-L }}$ and $\mathrm{NH}_{4}{ }^{+}$species during the increase in the adsorption temperature $\mathrm{T}_{\mathrm{a}}$ under isobaric condition, the AEIR method $[33,34]$ provides the evolution of the coverage of each adsorbed $\mathrm{NH}_{3}$ species and then either individual heats of adsorption considering (a) localized adsorbed species for the expression of their adsorption coefficients and (b) either the Temkin or the Langmuir adsorption model. These data allow determining the adsorption equilibrium coverage of each $\mathrm{NH}_{3}$ species for all sets of $T_{a}$ and $P_{a}$ values providing the coefficients of the $\Theta$ matrix.

The aim of the present study is to show the advantages and limits of the original method based on eq (1) for the determination of the amounts of the different acid sites of the three selected solids. Then, for the $\mathrm{NH}_{3}-\mathrm{SCR}$ catalyst, it is shown that these data allow identifying the acid site which is involved in the reaction by using transient experiments.

\section{Material and Methods}

\subsection{Solids, Preparation and Pretreatment Procedures}

Three $\mathrm{TiO}_{2}$ based solids of different compositions have been used (a) $\mathrm{TiO}_{2}-\mathrm{P} 25$ from Degussa $\left(\approx 55 \mathrm{~m}^{2} / \mathrm{g}, \approx 85 \%\right.$ anatase and $\approx 15 \%$ rutile with traces of $\left.\mathrm{SiO}_{2}: 0.2 \mathrm{wt} \%\right)$ and (b) two solids prepared in previous studies: a $6 \mathrm{wt} \% \mathrm{WO}_{3} / \mathrm{TiO}_{2}-\mathrm{P} 25$ [37] and a sulfated $0.7 \mathrm{wt} \%$ $\mathrm{V}_{2} \mathrm{O}_{5} / 9 \mathrm{wt} \% \mathrm{WO}_{3} / \mathrm{TiO}_{2}$ catalyst $\left(80 \mathrm{~m}^{2} / \mathrm{g}, 1.34 \% \mathrm{~S}\right)$ [38]. Briefly, the incipient wetness method has been used with aqueous solutions of (a) ammonium metatungstate for the 
deposition of $\mathrm{WO}_{3}$ on $\mathrm{TiO}_{2}-\mathrm{P} 25$ and (b) ammonium metavanadate dissolved in the presence of oxalic acid using as support the sulfated $9 \% \quad \mathrm{WO}_{3} / \mathrm{TiO}_{2}$ solid (DT52) from Millennium Inorganic Chemicals $\left(85 \mathrm{~m}^{2} / \mathrm{g}\right.$, pure anatase, $\left.1.35 \% \mathrm{~S}\right)$ [38]. After impregnation the solids were dried $24 \mathrm{~h}$ in air at room temperature and then $24 \mathrm{~h}$ at $110^{\circ} \mathrm{C}$ before heating $(\approx 1 \mathrm{~K} / \mathrm{min})$ to $713 \mathrm{~K}$ for $6 \mathrm{~h}$. Raman and IR spectroscopy have shown that depositions formed were welldispersed $\mathrm{VO}_{\mathrm{y}}$ and $\mathrm{WO}_{\mathrm{z}}$ groups (mono-oxo) with limited interactions between these groups and with the sulfate groups of DT52 [37, 38]. However, the composition was provided as $\mathrm{V}_{2} \mathrm{O}_{5}$ and $\mathrm{WO}_{3}$ similarly to literature data. Before $\mathrm{NH}_{3}$ adsorption the solids were treated on the analytical systems as follows: $\mathrm{O}_{2}(713 \mathrm{~K}, 10 \mathrm{~min}) \rightarrow \mathrm{He}(713 \mathrm{~K}, 5 \mathrm{~min}) \rightarrow \mathrm{He}$ (adsorption temperature $\mathrm{T}_{\mathrm{a}}$ ). The same catalyst sample was used to perform a series of experiments and it was pretreated as above before each experiment.

\subsection{Amounts of adsorbed $\mathrm{NH}_{3}$ species at $\mathrm{T}_{\mathrm{a}}$ and $\mathrm{P}_{\mathrm{a}}$ using a Mass Spectrometer (MS)}

The MS setup is the same that the one used in previous work [30, 37, 38]. Briefly, different valves allowed performing switches between controlled gas flow rates of known compositions (at atmospheric pressure) at the inlet of a quartz CSTR microreactor containing the solid supported on quartz wool. The solids were slightly compressed (density: $\approx 1.4 \mathrm{~g} / \mathrm{cm}^{3}$ ), crushed and sized $(\approx 230 \mu \mathrm{m})$ before using $\approx 0.15-0.3 \mathrm{~g}$ of particles. The temperature of the catalyst, controlled via a furnace of low inertia, was measured by a coaxial $\mathrm{K}$ type thermocouple $(\varnothing=0.25 \mathrm{~mm})$ inserted in the catalyst sample. A quadrupole mass spectrometer (Inficon, Transpector CPM) provided, via a selection of m/e peaks, the molar fractions of the gases at the reactor outlet after calibrations using gas mixtures of known compositions. The tubes, valves and inlet system of the MS were heated at $383 \mathrm{~K}$. The MS system provided the total amount of $\mathrm{NH}_{3}$ adsorbed at the adsorption equilibrium for adsorption temperature $\mathrm{T}_{\mathrm{a}}$ and pressure $\mathrm{P}_{\mathrm{a}}$ according to two procedures. The first was as follows: the pretreated solids were cooled in helium to the adsorption temperature $\mathrm{T}_{\mathrm{a}}\left(\mathrm{T}_{\mathrm{a}} \geq 300 \mathrm{~K}\right)$ and then a switch $\mathrm{He} \rightarrow \mathrm{x} \%$ 
$\mathrm{NH}_{3} / \mathrm{x} \% \mathrm{Ar} / \mathrm{He}$ was performed (Ar was a tracer) leading to the progressive attainment (with time on stream $t$ ) of the adsorption equilibrium at $\mathrm{T}_{\mathrm{a}}$ and $\mathrm{P}_{\mathrm{a}}=\mathrm{x} 10^{3} \mathrm{~Pa}$. The total amount of $\mathrm{NH}_{3}$ adsorption (i.e in $\mu \mathrm{mol} / \mathrm{g}$ of catalyst) was obtained from the integration of the apparent rate of $\mathrm{NH}_{3}$ adsorption according to:

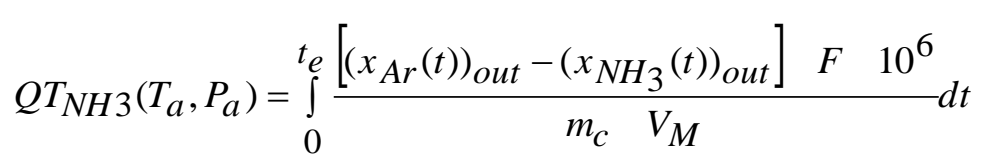

where, $\left(\mathrm{x}_{\mathrm{Ar}}(\mathrm{t})\right)_{\text {out }}$ and $\left(\mathrm{x}_{\mathrm{NH}}(\mathrm{t})\right)_{\text {out }}$ are the molar fractions of $\mathrm{Ar}$ and $\mathrm{NH}_{3}$ at the outlet of the reactor at time $\mathrm{t}$ (in $\mathrm{s}$ ) of the adsorption, $\mathrm{F}$ is the gas flow rate $\left(\mathrm{in} \mathrm{cm}^{3} / \mathrm{s}\right.$ ), $\mathrm{m}_{\mathrm{c}}$ is the mass of catalyst (in $\mathrm{g}$ ), $\mathrm{V}_{\mathrm{M}}$ is the gaseous molar volume in the experimental conditions of the measurement (in $\mathrm{cm}^{3} /$ mole) and $t_{e}$ is the duration to obtain the adsorption equilibrium corresponding to $\left(\mathrm{x}_{\mathrm{Ar}}\left(\mathrm{t}_{\mathrm{e}}\right)\right)_{\text {out }}=\left(\mathrm{x}_{\mathrm{NH}}\left(\mathrm{t}_{\mathrm{e}}\right)\right)_{\text {out }}$. The measurements were repeated after the pretreatment procedure of the solid sample using different $\mathrm{T}_{\mathrm{a}}$ or/and $\mathrm{P}_{\mathrm{a}}$. The amount of weakly adsorbed species at $\mathrm{T}_{\mathrm{a}}$ was obtained by the switch $\mathrm{x} \% \mathrm{NH}_{3} / \mathrm{x} \% \mathrm{Ar} / \mathrm{He} \rightarrow \mathrm{He}$. The second method for the measurement $\mathrm{QTNH}\left(\mathrm{T}_{\mathrm{a}}, \mathrm{P}_{\mathrm{a}}\right)$ was provided by the TPAE procedure [35] which permitted obtaining a number of values from one experiment according to the following procedure. After measuring $\mathrm{QTNH}_{3}\left(300 \mathrm{~K}, \mathrm{x} 10^{3} \mathrm{~Pa}\right)$ by the first method, $\mathrm{T}_{\mathrm{a}}$ was increased linearly (i.e $\alpha \approx 10 \mathrm{~K} / \mathrm{min}$ ) in the presence of $\mathrm{x} \% \mathrm{NH}_{3} / \mathrm{x} \% \mathrm{Ar} / \mathrm{He}$. This led to the progressive decrease in the adsorption equilibrium coverages of the different adsorbed $\mathrm{NH}_{3}$ species which was associated with the increase in the amount of $\mathrm{NH}_{3}$ in the gas phase (net $\mathrm{NH}_{3}$ desorption rate). According to the design of the TPAE experiment (by the selection of a set of $\alpha, \mathrm{m}_{\mathrm{c}}$ and $\mathrm{x}$ values) the increase in $\mathrm{P}_{\mathrm{NH} 3}$ in the CSTR reactor was limited to $\approx 30 \%$ of that at the inlet of the reactor $\left(\times 10^{3} \mathrm{~Pa}\right)$ which allowed assuming isobaric conditions favoring the exploitation of the experimental data [35]. The amount of $\mathrm{NH}_{3}$ removed from the surface (in $\mu \mathrm{mol} / \mathrm{g}$ ) by the increase from $\mathrm{T}_{\mathrm{a}}=300 \mathrm{~K}$ at $\mathrm{t}=0$ to $\mathrm{T}_{\mathrm{a}}=300+\alpha \mathrm{t}_{\mathrm{Ta}}$ was: 


$$
\mathrm{QDNH}_{3}\left(300 \mathrm{~K} \rightarrow \mathrm{T}_{\mathrm{a}}\right)=\int_{0}^{t_{T a}} \frac{\left.\left[\left(\left(x_{N H_{3}}(t)\right)_{\text {out }}-x_{A r}(t)\right)_{\text {out }}\right)\right]}{m_{c} V_{M}} 10^{6} d t
$$

and the total amount of $\mathrm{NH}_{3}$ adsorbed at $\mathrm{T}_{\mathrm{a}}$ and $\mathrm{P}_{\mathrm{a}} \approx \mathrm{x} 10^{3} \mathrm{~Pa}$ (in $\left.\mu \mathrm{mol} / \mathrm{g}\right)$ was:

$$
\mathrm{QTNH}_{3}\left(\mathrm{~T}_{\mathrm{a}}, \mathrm{x} 10^{3} \mathrm{P}_{\mathrm{a}}\right)=\mathrm{QTNH}_{3}\left(300 \mathrm{~K}, \mathrm{x} 10^{3} \mathrm{~Pa}\right)-\mathrm{QDNH}_{3}\left(300 \mathrm{~K} \rightarrow \mathrm{T}_{\mathrm{a}}\right)
$$

Similar calculations were made for different $\mathrm{t}_{\mathrm{Ta}}$ providing, from one experiment a set of $\mathrm{QTNH}_{3}\left(\mathrm{~T}_{\mathrm{a}}, \mathrm{x} 10^{3} \mathrm{P}_{\mathrm{a}}\right)$ values for $\mathrm{T}_{\mathrm{a}} \geq 300 \mathrm{~K}$ with an accuracy of $\approx \pm 5 \mu \mathrm{mol} / \mathrm{g}$.

\subsection{IR cell Microreactor}

FTIR characterizations of the adsorbed $\mathrm{NH}_{3}$ species have been performed using a Nicolet-6700 FTIR spectrometer equipped with a small pathlength $(\approx 2 \mathrm{~mm})$ home made stainless steel IR cell in transmission mode using $\mathrm{CaF}_{2}$ windows and described in more details previously [39]. Briefly, it allowed in-situ treatments of a compressed disk of solid $(\Phi=2.1$ $\mathrm{cm}, \mathrm{m} \approx 40-80 \mathrm{mg}$ ), in the $293-800 \mathrm{~K}$ temperature range with a controlled gas flow rate in the range of $150-2000 \mathrm{~cm}^{3} / \mathrm{min}$ at atmospheric pressure selected using different switching valves and purified by different traps in particular cold traps for $\mathrm{H}_{2} \mathrm{O}$ impurities (77 $\mathrm{K}$ using helium). The FTIR system has been used for the identification of the adsorbed $\mathrm{NH}_{3}$ species and their evolution at the adsorption equilibrium for $\mathrm{T}_{\mathrm{a}} \geq 300 \mathrm{~K}$ using $\mathrm{x} \% \mathrm{NH}_{3} / \mathrm{He}$ gas mixtures.

\section{Results and Discussion}

The procedure for the measurement of the individual amounts of acid sites on metal oxides using $\mathrm{NH}_{3}$ adsorption equilibrium is presented by its application to the solid having the simplest composition: $\mathrm{TiO}_{2}-\mathrm{P} 25$ and then to $\mathrm{WO}_{3} / \mathrm{TiO}_{2}$ and $\mathrm{V}_{2} \mathrm{O}_{5} / \mathrm{WO}_{3} / \mathrm{TiO}_{2}$.

\subsection{Individual amounts of the acid sites on $\mathrm{TiO}_{2} \mathrm{P} 25$ using $\mathrm{NH}_{3}$}

Equation (1) imposes the identification of the different acid sites on the surface of the pretreated solid for the adsorption of $\mathrm{NH}_{3}$. This has been done by using FTIR spectroscopy [30] and the main results and conclusions are briefly summarized to facilitate the presentation. In the range $1700-1100 \mathrm{~cm}^{-1}$, the adsorption of $0.1 \% \mathrm{NH}_{3} / \mathrm{He}$ at $300 \mathrm{~K}$ on $\mathrm{TiO}_{2}-\mathrm{P} 25$ leads to 
spectrum a in Fig. 1 with IR bands similar to those observed by different authors on the same solid and ascribed as follows [10-13]: (a) the strong IR band at $1142 \mathrm{~cm}^{-1}$ and the shoulder at $1215 \mathrm{~cm}^{-1}$ comes from the $\delta_{\mathrm{s}}$ vibrations of two adsorbed $\mathrm{NH}_{3}$ species on different LAS named $\mathrm{NH}_{3 \text { ads-L1 }}$ and $\mathrm{NH}_{3 \text { ads-L2 }}$ respectively, (b) the IR band at $1596 \mathrm{~cm}^{-1}$ is due to the overlap of the $\delta_{\text {as }}$ vibrations of these two species, (c) the broad and weak IR band at $1475 \mathrm{~cm}^{-1}$ and the shoulder at $1680 \mathrm{~cm}^{-1}$ are ascribed to the deformation vibrations of $\mathrm{NH}_{4}{ }^{+}-\mathrm{B}$ species formed on a BAS. Considering DFT literature data, the two types of LAS have been located on different surfaces of $\mathrm{TiO}_{2}$ particles [30].

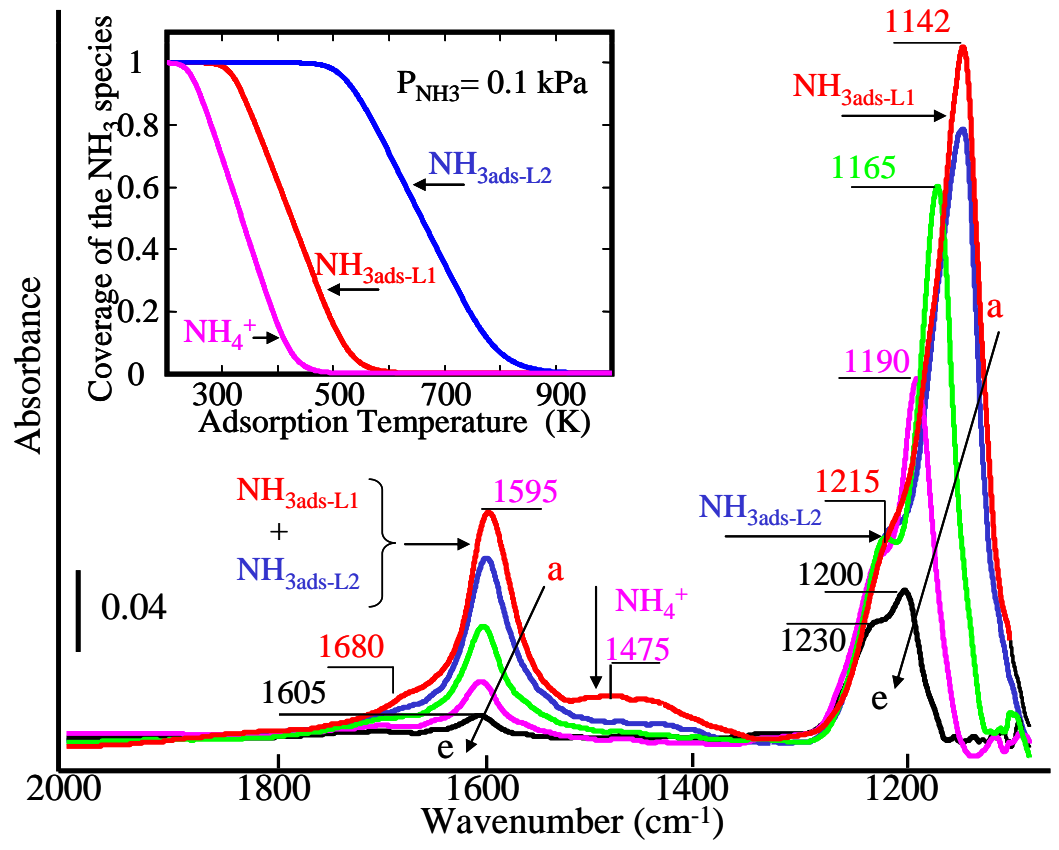

Figure 1: FTIR spectra of adsorbed species formed by $\mathrm{NH}_{3}$ on $\mathrm{TiO}_{2}-\mathrm{P} 25$ at different adsorption temperature $\mathrm{T}_{\mathrm{a}}$ using $0.1 \% \mathrm{NH}_{3} / \mathrm{He}$ : (a)-(e) $\mathrm{T}_{\mathrm{a}}=300,373,473,573$ and $673 \mathrm{~K}$. Inset: Evolution of the coverage of the three adsorbed $\mathrm{NH}_{3}$ species with $\mathrm{T}_{\mathrm{a}}$ for $\mathrm{P}_{\mathrm{NH} 3}=0.1 \mathrm{kPa}$ according to eqs (ES1)-(ES2) and the heats of adsorption in Table 1.

It has been shown [30] that the intensities of the IR bands of the $\mathrm{NH}_{3 \text { ads-L }}$ species are not modified at $\mathrm{T}_{\mathrm{a}}=300 \mathrm{~K}$ by increasing $\mathrm{P}_{\mathrm{NH} 3}$ from $0.1 \mathrm{kPa}$ to $1 \mathrm{kPa}$, indicating the saturation of the two LAS due to the high heats of adsorption of the two $\mathrm{NH}_{3 \text { ads-L }}$ species (strong LAS) whereas the intensity of the IR bands of the $\mathrm{NH}_{4}{ }^{+}-\mathrm{B}$ species increases (weak BAS). The evolutions of the IR bands with the increase in the $T_{a}$ for $P_{a}=0.1 \mathrm{kPa}$ (Fig. 1 spectra b-e) show 
that (a) the IR bands of the $\mathrm{NH}_{4}{ }^{+}$species disappear at $\mathrm{T}_{\mathrm{a}} \approx 393 \mathrm{~K}$, (b) the $\delta_{\mathrm{s}}$ IR band of $\mathrm{NH}_{3 \mathrm{ads}-\mathrm{L} 1}$ species decreases significantly in the $\mathrm{T}_{\mathrm{a}}$ range of $300-573 \mathrm{~K}$ (associated to a shift to higher wavenumbers: i.e. from $1142 \mathrm{~cm}^{-1}$ to $1190 \mathrm{~cm}^{-1}$ at $300 \mathrm{~K}$ and $573 \mathrm{~K}$ respectively) and (c) the $\delta_{\mathrm{s}}$ IR band of $\mathrm{NH}_{3}$ ads-L2 species is unmodified until $\mathrm{T}_{\mathrm{a}} \approx 590 \mathrm{~K}$ and then it decreases progressively. This indicates that the strength of the LAS are in the order L2 > L1. The data in Fig. 1 indicate that eq. (1) for $\mathrm{TiO}_{2}-\mathrm{P} 25$ is:

$$
\mathrm{QTNH}_{3}\left(\mathrm{~T}_{\mathrm{a}}, \mathrm{P}_{\mathrm{a}}\right)=\mathrm{Q}_{\mathrm{L} 1} \theta_{\mathrm{NH} 3 \mathrm{ads}-\mathrm{L} 1}\left(\mathrm{~T}_{\mathrm{a}}, \mathrm{P}_{\mathrm{a}}\right)+\mathrm{Q}_{\mathrm{L} 2} \theta_{\mathrm{NH} 3 \mathrm{ads}-\mathrm{L} 2}\left(\mathrm{~T}_{\mathrm{a}}, \mathrm{P}_{\mathrm{a}}\right)+\mathrm{Q}_{\mathrm{B}} \theta_{\mathrm{NH} 4}{ }_{-\mathrm{B}} \mathrm{B}\left(\mathrm{T}_{\mathrm{a}}, \mathrm{P}_{\mathrm{a}}\right)
$$

The amounts of $\mathrm{B}, \mathrm{L} 1$ and $\mathrm{L} 2$ acid sites in eq. (6): $\mathrm{Q}_{\mathrm{B}}, \mathrm{Q}_{\mathrm{L} 1}$ and $\mathrm{Q}_{\mathrm{L} 2}$ respectively can be obtained by measuring $\mathrm{QTNH}_{3}\left(\mathrm{~T}_{\mathrm{a}}, \mathrm{P}_{\mathrm{a}}\right)$ at three adsorption equilibrium conditions. In eq. (6), the adsorption equilibrium coverages of the $\mathrm{NH}_{3 a d s-L 1}, \mathrm{NH}_{3 \text { ads-L2 }}$ and $\mathrm{NH}_{4}{ }^{+}$species at $\mathrm{T}_{\mathrm{a}}$ and $\mathrm{P}_{\mathrm{a}}$ are known $[30,40]$ from the application of the AEIR method.

\begin{tabular}{|c|c|c|c|c|c|c|}
\hline \multirow[t]{2}{*}{ Solid } & \multicolumn{3}{|c|}{$\mathrm{NH}_{3 \text { ads-L1 }}$} & \multicolumn{3}{|c|}{$\mathrm{NH}_{3 \text { ads-L2 }}$} \\
\hline & $\mathrm{E}(1) \mathrm{kJ} / \mathrm{mol}$ & $\mathrm{E}(0) \mathrm{kJ} / \mathrm{mol}$ & $\mathrm{x}_{1}$ & $\mathrm{E}(1) \mathrm{kJ} / \mathrm{mol}$ & $\mathrm{E}(0) \mathrm{kJ} / \mathrm{mol}$ & $\mathrm{x}_{2}$ \\
\hline $\mathrm{TiO}_{2}-\mathrm{P} 25^{\mathrm{a}}$ & 58 & 102 & 0.73 & 102 & 160 & 0.27 \\
\hline $6 \% \mathrm{WO}_{3} / \mathrm{TiO}_{2}-\mathrm{P} 25^{\mathrm{b}}$ & 55 & 105 & 0.65 & 110 & 147 & 0.35 \\
\hline \multirow{3}{*}{$0.7 \% \mathrm{~V}_{2} \mathrm{O}_{5} / 9 \% \mathrm{WO}_{3} / \mathrm{TiO}_{2}-\mathrm{S}^{\mathrm{b}}$} & 59 & 97 & 0.65 & 100 & 142 & 0.35 \\
\hline & \multicolumn{3}{|c|}{$\mathrm{NH}_{4}^{+}-\mathrm{B} 1$} & \multicolumn{3}{|c|}{$\mathrm{NH}_{4}^{+}-\mathrm{B} 2$} \\
\hline & $\mathrm{E}(1) \mathrm{kJ} / \mathrm{mol}$ & $\mathrm{E}(0) \mathrm{kJ} / \mathrm{mol}$ & $\mathrm{x}_{1}$ & $\mathrm{E}(1) \mathrm{kJ} / \mathrm{mol}$ & $\mathrm{E}(1) \mathrm{kJ} / \mathrm{mol}$ & $\mathrm{x}_{2}$ \\
\hline $\mathrm{TiO}_{2}-\mathrm{P} 25^{\mathrm{c}, *}$ & 43 & 80 & 1 & & & 0 \\
\hline $6 \% \mathrm{WO}_{3} / \mathrm{TiO}_{2}-\mathrm{P} 25^{\mathrm{b}}$ & 59 & 105 & 0.60 & 75 & 140 & 0.40 \\
\hline $0.7 \% \mathrm{~V}_{2} \mathrm{O}_{5} / 9 \% \mathrm{WO}_{3} / \mathrm{TiO}_{2}-\mathrm{S}^{\mathrm{b}}$ & 57 & 90 & 0.65 & 75 & 135 & 0.35 \\
\hline
\end{tabular}

Table 1: Heats of adsorption at low $(\mathrm{E}(0))$ and high $(\mathrm{E}(1)$ coverages (accuracy $\approx \pm 5 \mathrm{~kJ} / \mathrm{mol})$ and proportions of the adsorbed $\mathrm{NH}_{3}$ species on three $\mathrm{TiO}_{2}$ based solid according to the AEIR method.

It has been shown $[30,40]$ that their coverages follow the Temkin adsorption model (eq. ES1 in SI) with heats of adsorption decreasing linearly with the increase in the coverage and Table 1 gives the values at low and high coverages for the three species assuming localized 
adsorbed species for their adsorption coefficients (eq ES2 in SI). The accuracy on the heats of adsorption provided by the AEIR method is of $\approx \pm 5 \mathrm{~kJ} / \mathrm{mol}[33,34]$. From the data in Table 1 and eqs ES1-ES2, the individual coverages of the three adsorbed $\mathrm{NH}_{3}$ species on the pretreated $\mathrm{TiO}_{2}-\mathrm{P} 25$ can be determined whatever $\mathrm{T}_{\mathrm{a}}$ and $\mathrm{P}_{\mathrm{a}}$. For instance, the inset of Fig. 1 shows the evolution of the coverages with $\mathrm{T}_{\mathrm{a}}$ in isobaric conditions for $\mathrm{P}_{\mathrm{a}}=0.1 \mathrm{kPa}$ : it can be observed that at $\mathrm{T}_{\mathrm{a}}=300 \mathrm{~K}$, the coverage of the $\mathrm{NH}_{3 \mathrm{ads}-\mathrm{L} 1}$ and $\mathrm{NH}_{3 \mathrm{ads}-\mathrm{L} 2}$ species is 1 for $\mathrm{P}_{\mathrm{a}}=0.1 \mathrm{kPa}$ and that their individual amounts are those of $\mathrm{Q}_{\mathrm{L} 1}$ and $\mathrm{Q}_{\mathrm{L} 2}$ respectively. This means that considering spectrum a in Fig. 1 recorded at $300 \mathrm{~K}$ and assuming similar IR extinction coefficients for the $\delta_{\mathrm{s}}$ IR bands at 1142 and $1215 \mathrm{~cm}^{-1}$, then the ratio of their intensities (after their decomposition [30]) provides that of $\mathrm{Q}_{\mathrm{L} 1} / \mathrm{Q}_{\mathrm{L} 2}$ and then to the contributions (in proportion) of the $\mathrm{L} 1$ and $\mathrm{L} 2$ sites to the total amount of LAS: $\mathrm{x}_{1} \approx 0.7$ and $\mathrm{x}_{2} \approx 0.3[30]$. Using the evolution of the intensity of their common IR band at $1596 \mathrm{~cm}^{-1}$ with the increase in $T_{a}$ in isobaric condition, AEIR method provided accurate values of $\mathrm{x}_{1}$ and $\mathrm{x}_{2}[30]$ as indicated in Table 1 . The interest of $\mathrm{x}_{1}$ and $\mathrm{x}_{2}$ for the present study is that the relationship $\mathrm{Q}_{\mathrm{L} 1}=\left(\mathrm{x}_{1} / \mathrm{x}_{2}\right) \mathrm{Q}_{\mathrm{L} 2}$ may reduce the number of unknown parameters in eq. (6) to two (i.e $\mathrm{Q}_{\mathrm{B}}$ and $\mathrm{Q}_{\mathrm{L} 2}$ ).

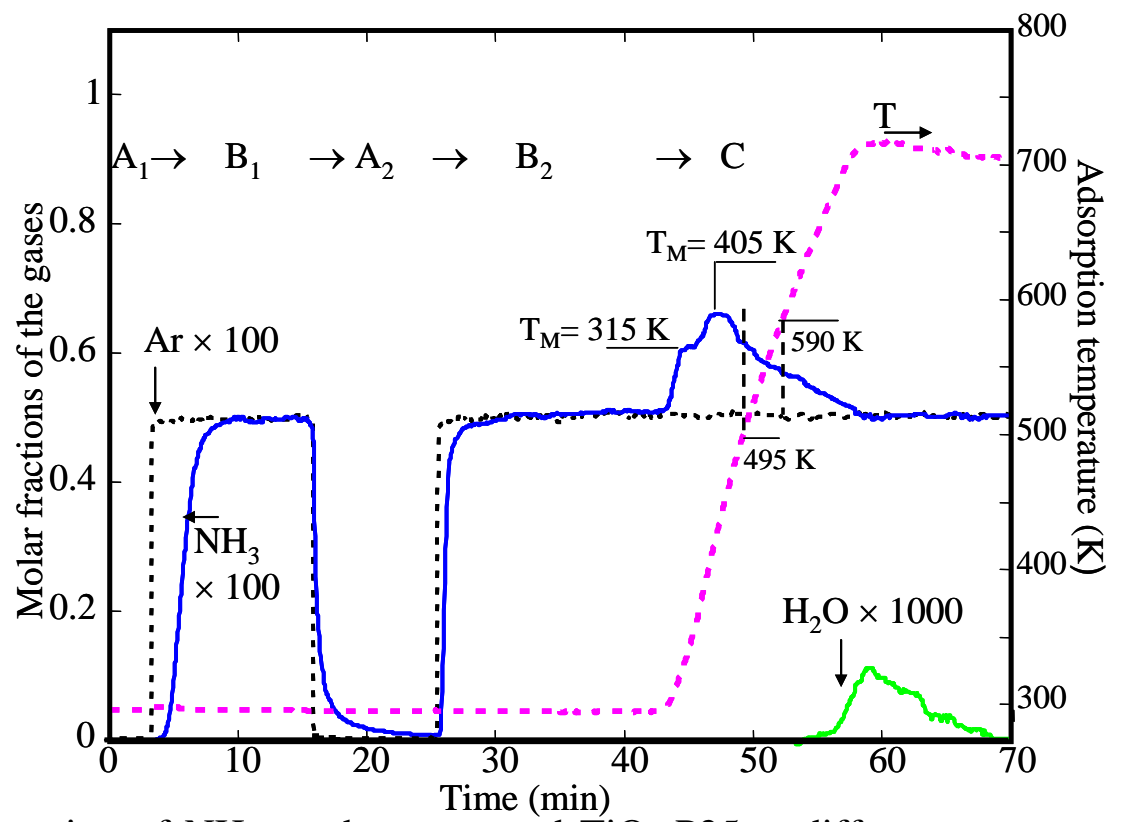

Figure 2: Adsorption of $\mathrm{NH}_{3}$ on the pretreated $\mathrm{TiO}_{2}-\mathrm{P} 25$ at different temperatures using the M.S system: Parts $\mathrm{A}_{1}$ and $\mathrm{A}_{2}$ in Helium and Parts $\mathrm{B}_{1}$ and $\mathrm{B}_{2}$ in $0.5 \% \mathrm{NH}_{3} / 0.5 \% \mathrm{Ar} / \mathrm{He}$ at $300 \mathrm{~K}$ : Part $\mathrm{C}$ increase in $\mathrm{T}_{\mathrm{a}}$ from 300 to $715 \mathrm{~K}$ (TPAE procedure). 
The measurements of $\mathrm{QTNH}_{3}\left(\mathrm{~T}_{\mathrm{a}}, \mathrm{P}_{\mathrm{a}}\right)$ under different experimental conditions have been performed with the MS system according to Fig. 2 which shows the evolutions of the Ar and $\mathrm{NH}_{3}$ molar fractions during the switch $\mathrm{He}\left(\operatorname{Part} \mathrm{A}_{1}\right) \rightarrow 0.5 \% \mathrm{NH}_{3} / 0.5 \% \mathrm{Ar} / \mathrm{He}\left(\operatorname{Part} \mathrm{B}_{1}\right)$ at 300 $\mathrm{K}$ on the pretreated $\mathrm{TiO}_{2}-\mathrm{P} 25$ solid. The total amount of $\mathrm{NH}_{3}$ adsorbed at the adsorption equilibrium (eq. (3)) is $\mathrm{QTNH}_{3}(300 \mathrm{~K}, 0.5 \mathrm{kPa})=332 \mu \mathrm{mol}$ of $\mathrm{NH}_{3} / \mathrm{g}$ due to the $\mathrm{NH}_{3 \text { ads-L1}}$, $\mathrm{NH}_{3 \text { ads-L2 }}$ and $\mathrm{NH}_{4}{ }^{+}-\mathrm{B}$ adsorbed species (Fig. 1). Equations ES1-ES2 and Table 1 indicate that

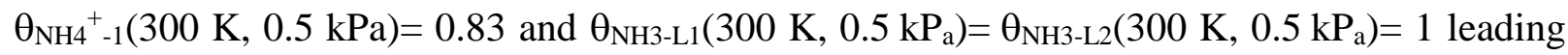
to the first equation of a three linear equations system:

$$
0.83 \mathrm{Q}_{\mathrm{B}}+\mathrm{Q}_{\mathrm{L} 1}+\mathrm{Q}_{\mathrm{L} 2}=332 \mu \mathrm{mol} / \mathrm{g}
$$

The switch $0.5 \% \mathrm{NH}_{3} / 0.5 \% \mathrm{Ar} / \mathrm{He}\left(\mathrm{Part}_{1}\right) \rightarrow \mathrm{He}\left(\right.$ Part $\left.\mathrm{A}_{2}\right)$ leads to the desorption of $96 \mu \mathrm{mol}$ of $\mathrm{NH}_{3} / \mathrm{g}$ ascribed to the weakly adsorbed $\mathrm{NH}_{4}{ }^{+}-\mathrm{B}$ species and a fraction of the $\mathrm{NH}_{3}$ ads-L1 species. This amount is readsorbed during the following switch $\mathrm{He}\left(\mathrm{Part} \mathrm{A}_{2}\right) \rightarrow 0.5 \%$ $\mathrm{NH}_{3} / 0.5 \% \mathrm{Ar} / \mathrm{He}\left(\right.$ Part $\mathrm{B}_{2}$ ). The increase in $\mathrm{T}_{\mathrm{a}}$ (Part $\mathrm{C}$ of Fig. 2) in the presence of $0.5 \%$ $\mathrm{NH}_{3} / 0.5 \% \mathrm{Ar} / \mathrm{He}$ (TPAE procedure) leads to a net $\mathrm{NH}_{3}$ desorption due to the progressive decrease in the adsorption equilibrium coverages of the three adsorbed species (inset of Figure 1) according to a broad peak with a maximum at $\mathrm{T}_{\mathrm{m}}=405 \mathrm{~K}$ and a shoulder at $315 \mathrm{~K}$. At the end of the heating stage for $\mathrm{T}_{\mathrm{a}} \approx 710 \mathrm{~K}$, the molar fractions of $\mathrm{NH}_{3}$ and $\mathrm{Ar}$ are equal indicating the attainment of the adsorption equilibrium for $\mathrm{T}_{\mathrm{a}}=710 \mathrm{~K}$ and $\mathrm{P}_{\mathrm{a}}=0.5 \mathrm{kPa}$. Figure 2 shows that there is a small $\mathrm{H}_{2} \mathrm{O}$ production at high temperatures (without $\mathrm{N}_{2}$ production) ascribed to the dehydration of the solid in the presence of adsorbed $\mathrm{NH}_{3}$ species [30] and references therein. The accuracy on the measurements of the amount of $\mathrm{NH}_{3}$ removed from the surface (eq. (4)) in the high $\mathrm{T}_{\mathrm{a}}$ range is limited because for low apparent $\mathrm{NH}_{3}$ desorption rates the difference between the molar fractions of $\mathrm{Ar}$ and $\mathrm{NH}_{3}$ is very small. This means that $\mathrm{QTNH}_{3}\left(\mathrm{~T}_{\mathrm{a}}, \mathrm{P}_{\mathrm{a}}\right)$ from eqs (4)-(5) must be measured for $\mathrm{T}_{\mathrm{a}} \leq \approx 650 \mathrm{~K}$. Note that the highest adsorption pressure in the CSTR reactor: $0.65 \mathrm{~Pa}$ at $\mathrm{T}_{\mathrm{a}}=405 \mathrm{~K}$ permits assuming quasi isobaric 
condition during the TPAE [35]. Part C in Fig. 2 and eqs (4)-(5) provide the experimental evolution of the total amount of $\mathrm{NH}_{3}$ adsorbed at the adsorption equilibrium on $\mathrm{TiO}_{2}-\mathrm{P} 25$ with the increase in $T_{a}$ in quasi isobaric conditions as shown by curve a in Fig. 3 (symbols

obtained for time intervals of $\approx 60 \mathrm{~s}$. These data are used to discuss the advantages and limits of two calculation methods (named M1 and M2) for the determination of $\mathrm{Q}_{\mathrm{B}}$, $\mathrm{Q}_{\mathrm{L} 1}$ and $\mathrm{Q}_{\mathrm{L} 2}$.

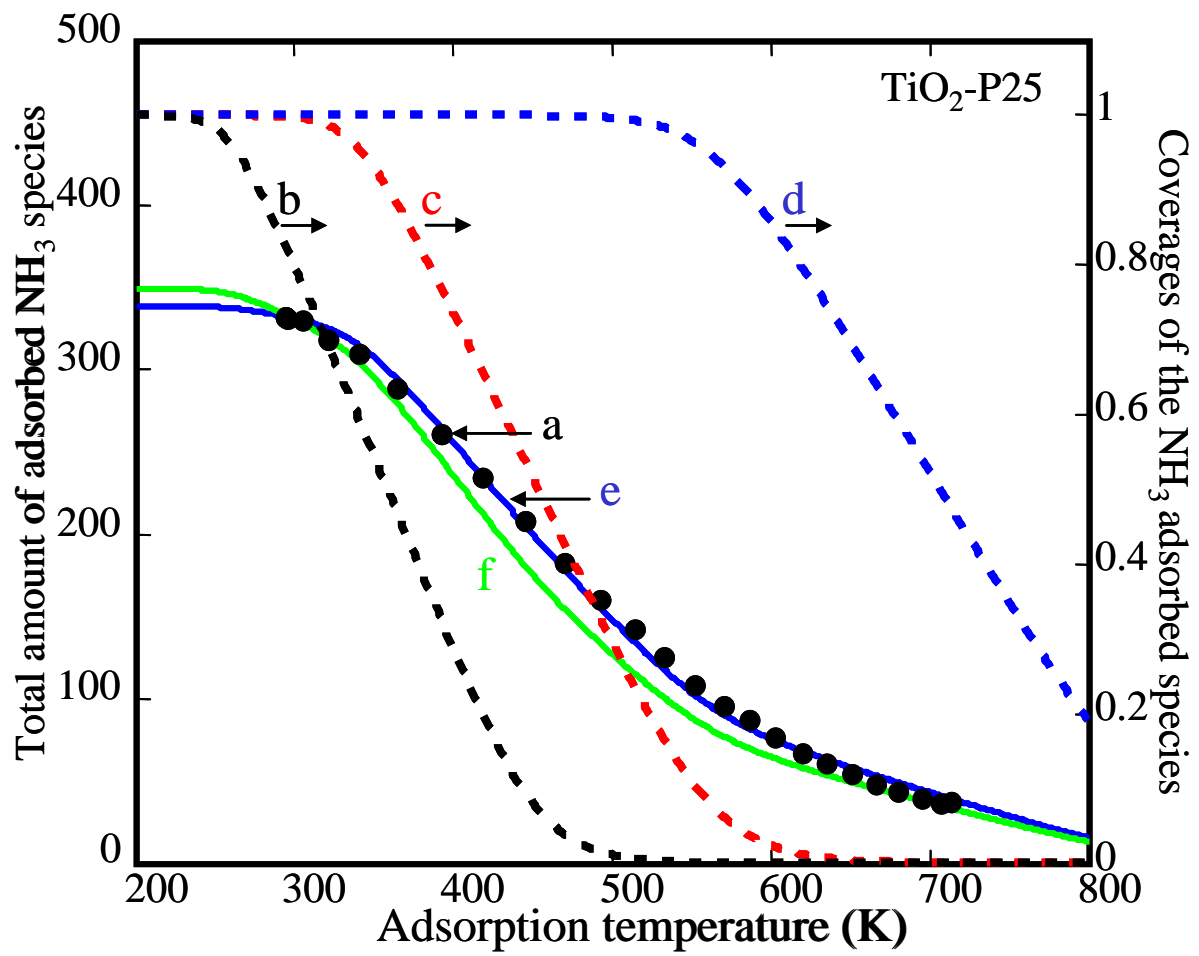

Figure 3: Total amount of $\mathrm{NH}_{3}$ adsorbed and coverage of the adsorbed $\mathrm{NH}_{3}$ species on $\mathrm{TiO}_{2}-$ P25 at different adsorption temperatures $\mathrm{T}_{\mathrm{a}}$ : (a) experimental amount for $\mathrm{NH}_{3}$ from part $\mathrm{C}$ in Fig.2; (b), (c) and (d) coverages of the $\mathrm{NH}_{4}{ }^{+}-\mathrm{B}, \mathrm{NH}_{3 \text { ads-L1 }}$ and $\mathrm{NH}_{3 \text { ads-L2 }}$ species respectively for $\mathrm{Pa}=0.5 \mathrm{kPa}$; (e) theoretical total of $\mathrm{NH}_{3}$ adsorbed considering $\mathrm{Q}_{\mathrm{B}}=22.5 \mu \mathrm{mol} / \mathrm{g}, \mathrm{Q}_{\mathrm{L} 1}=225$ $\mu \mathrm{mol} / \mathrm{g}$ and $\mathrm{Q}_{\mathrm{L} 2}=83.4 \mu \mathrm{mol} / \mathrm{g}$; (f) theoretical total of $\mathrm{NH}_{3}$ adsorbed considering $\mathrm{Q}_{\mathrm{B}}=22.5$ $\mu \mathrm{mol} / \mathrm{g}, \mathrm{Q}_{\mathrm{L} 1}=225 \mu \mathrm{mol} / \mathrm{g}$ and $\mathrm{Q}_{\mathrm{L} 2}=83.4 \mu \mathrm{mol} / \mathrm{g}$.

\subsubsection{Individual amount of acid sites on $\mathrm{TiO}_{2}-\mathrm{P} 25$ from method $\mathrm{M} 1$}

The acidic properties of $\mathrm{TiO}_{2}-\mathrm{P} 25$ offer a favorable situation for the measurement of $\mathrm{Q}_{\mathrm{B}}, \mathrm{Q}_{\mathrm{L} 1}$ and $\mathrm{Q}_{\mathrm{L} 2}$ as shown by the evolutions of the coverages of the $\mathrm{NH}_{4}{ }^{+}-\mathrm{B}, \mathrm{NH}_{3 \text { ads-L1 }}$ and $\mathrm{NH}_{3 \text { ads-L2 }}$ species (curves $b$, $c$ and $d$ in Fig. 3 respectively) with $T_{a}$ for $P_{a}=0.5 \mathrm{kPa}$ using eqs (ES1)-(ES2) and the heats of adsorption from Table 1. These curves show that $\mathrm{QTNH}_{3}\left(\mathrm{~T}_{\mathrm{a}}, \mathrm{P}_{\mathrm{a}}\right)$ 
is due to (a) only $\mathrm{L} 2$ at $\mathrm{T}_{\mathrm{a}} \geq 620 \mathrm{~K}$, (b) $\mathrm{L} 1$ and $\mathrm{L} 2$ in the $520-620 \mathrm{~K}$ range and (c) the three acid sites in the $300-520 \mathrm{~K}$ range. This situation leads to a triangular $(3 \times 3) \Theta$ matrix (eq. (2)) providing easily the different amounts of acid sites. For instance at $T_{a}=620 \mathrm{~K}: \mathrm{Q}_{\mathrm{NH}}(620 \mathrm{~K}, 0.5$ $\mathrm{kPa})=66 \mu \mathrm{mol} / \mathrm{g}\left(\right.$ curve a Fig. 3) while $\theta_{\mathrm{NH} 3-\mathrm{L} 2}(620 \mathrm{~K}, 0.5 \mathrm{kPa})=0.78$ (curve $\mathrm{d}$ in Fig. 3) leading to $\mathrm{Q}_{\mathrm{L} 2} \approx 84 \mu \mathrm{mol} / \mathrm{g}$. Similarly, in Fig. 3 for $\mathrm{T}_{\mathrm{a}}=550 \mathrm{~K}$ : $\mathrm{Q}_{\mathrm{NH} 3}(550 \mathrm{~K}, \approx 0.5 \mathrm{kPa})=107$ $\mu \mathrm{mol} / \mathrm{g}$ (curve a, Fig. 3) while $\theta_{\mathrm{NH} 3-\mathrm{L} 1}(550 \mathrm{~K}, 0.5 \mathrm{kPa})=0.11$ and $\theta_{\mathrm{NH} 3-\mathrm{L} 2}(550 \mathrm{~K}, 0.5 \mathrm{kPa})=$ 0.97 leading to: $\left(0.11 \mathrm{Q}_{\mathrm{L} 1}+0.97 \mathrm{Q}_{\mathrm{L} 2}\right)=107 \mu \mathrm{mol} / \mathrm{g}$ and then $\mathrm{Q}_{\mathrm{L} 1}=227 \mu \mathrm{mol} / \mathrm{g}$. Note that $\mathrm{Q}_{\mathrm{L} 2} /\left(\mathrm{Q}_{\mathrm{L} 1}+\mathrm{Q}_{\mathrm{L} 2}\right)=0.27$ which is consistent with the data in Table 1 obtained from the AEIR method. Finally, eq. (7) for the adsorption at $300 \mathrm{~K}$ provides $\mathrm{Q}_{\mathrm{B}}=25 \mu \mathrm{mol} / \mathrm{g}$.

For solids having different acidic properties, the above calculations are not allowed: the $\Theta$ matrix is rarely triangular due to the contributions of several adsorbed $\mathrm{NH}_{3}$ species to $\mathrm{QTNH}_{3}\left(\mathrm{~T}_{\mathrm{a}}, \mathrm{P}_{\mathrm{a}}\right)$ in the available $\mathrm{T}_{\mathrm{a}}$ and $\mathrm{P}_{\mathrm{a}}$ ranges. The impacts of this situation can be evaluated using the data on $\mathrm{TiO}_{2}-\mathrm{P} 25$ for $\mathrm{T}_{\mathrm{a}}<460 \mathrm{~K}$ such as $\mathrm{T}_{\mathrm{a}}=300 \mathrm{~K}, 392 \mathrm{~K}$ and $445 \mathrm{~K}$ (see Fig. 3 curves b, c, d) corresponding to $\mathrm{QTNH}_{3}\left(\mathrm{~T}_{\mathrm{a}}, \mathrm{P}_{\mathrm{a}}\right)$ of $332 \mu \mathrm{mol} / \mathrm{g}, 261 \mu \mathrm{mol} / \mathrm{g}$ and $204 \mu \mathrm{mol} / \mathrm{g}$ respectively (Fig. 3 curve a) leading to the linear equation system:

$$
\begin{aligned}
& 0.83 \mathrm{Q}_{\mathrm{B}}+\mathrm{Q}_{\mathrm{L} 1}+\mathrm{Q}_{\mathrm{L} 2}=332 \\
& 0.33 \mathrm{Q}_{\mathrm{B}}+0.77 \mathrm{Q}_{\mathrm{L} 1}+\mathrm{Q}_{\mathrm{L} 2}=261 \\
& 0.096 \mathrm{Q}_{\mathrm{B}}+0.54 \mathrm{Q}_{\mathrm{L} 1}+\mathrm{Q}_{\mathrm{L} 2}=204
\end{aligned}
$$

The numerical solutions of this system (using Mathcad) are significantly different from those determined using the triangular $\Theta$ matrix: $\mathrm{Q}_{\mathrm{B}} \approx 52 \mu \mathrm{mol} / \mathrm{g}, \mathrm{Q}_{\mathrm{L} 1} \approx 194 \mu \mathrm{mol} / \mathrm{g}$ and $\mathrm{Q}_{\mathrm{L} 2} \approx 94$ $\mu \mathrm{mol} / \mathrm{g}$. This is due to the impacts of the experimental uncertainties on $\mathrm{QTNH}_{3}\left(\mathrm{~T}_{\mathrm{a}}, \mathrm{P}_{\mathrm{a}}\right)$. For instance, assuming in eq. (10) that at $445 \mathrm{~K}$ the amount of adsorbed $\mathrm{NH}_{3}$ species is $207 \mu \mathrm{mol} / \mathrm{g}$ then the solutions of the linear equation are $\mathrm{Q}_{\mathrm{B}} \approx 64 \mu \mathrm{mol} / \mathrm{g}, \mathrm{Q}_{\mathrm{L} 1} \approx 170 \mu \mathrm{mol} / \mathrm{g}$ and $\mathrm{Q}_{\mathrm{L} 2} \approx 109$ $\mu \mathrm{mol} / \mathrm{g}$. For solids having more complex acidic properties than $\mathrm{TiO}_{2}-\mathrm{P} 25$, the experimental uncertainties on $\mathrm{QTNH}_{3}\left(\mathrm{~T}_{\mathrm{a}}, \mathrm{P}_{\mathrm{a}}\right)$ may lead to numerical solutions with negative values. This 
situation can be overcome by using a calculation method taking into account a large number of experimental data as shown for the $\mathrm{TiO}_{2}-\mathrm{P} 25$ solid.

\subsubsection{Individual amount of acid sites on $\mathrm{TiO}_{2}-\mathrm{P} 25$ from method $\mathrm{M} 2$}

This method is based on the determination of $\mathrm{Q}_{\mathrm{B}}, \mathrm{Q}_{\mathrm{L} 1}$ and $\mathrm{Q}_{\mathrm{L} 2}$ by optimization of their values to obtain an agreement between the experimental $Q_{\mathrm{NH} 3}\left(T_{a}, P_{a}\right)=f\left(T_{a}\right)$ curve (i.e curve a in Fig. 3) at $\mathrm{P}_{\mathrm{a}} \approx 0.5 \mathrm{kPa}$ and the theoretical curve provided by eq. (6). To facilitate the optimization procedure, the relationship: $\mathrm{Q}_{\mathrm{L} 1} / \mathrm{Q}_{\mathrm{L} 2}=\mathrm{x}_{1} / \mathrm{x}_{2}=0.73 / 0.27$ (Table 1 ) is used to reduce the number of variables and eq. (6) gives:

$$
\left.\mathrm{QTNH}_{3}\left(\mathrm{~T}_{\mathrm{a}}, \mathrm{P}_{\mathrm{a}}\right)=\mathrm{Q}_{\mathrm{B}} \theta_{\mathrm{NH} 4}{ }^{+}{ }_{-\mathrm{B}}\left(\mathrm{T}_{\mathrm{a}}, \mathrm{P}_{\mathrm{a}}\right)+\mathrm{Q}_{\mathrm{L} 2}\left[0.73 \theta_{\mathrm{NH} 3-\mathrm{L} 1}\left(\mathrm{~T}_{\mathrm{a}}, \mathrm{P}_{\mathrm{a}}\right) / 0.27\right)+\theta_{\mathrm{NH} 3-\mathrm{L} 2}\left(\mathrm{~T}_{\mathrm{a}}, \mathrm{P}_{\mathrm{a}}\right)\right]
$$

In eq. (11) the different coverages are provided by the Temkin adsorption model assuming localized adsorbed species (eqs ES1-ES2) with the heats of adsorption in Table 1. An optimization function (i.e. Minerr of Mathcad) indicates that the best agreement between eq. (11) and curve a in Fig. 3 is obtained using $\mathrm{Q}_{\mathrm{B}}=22 \mu \mathrm{mol} / \mathrm{g}$ and $\mathrm{Q}_{\mathrm{L} 2}=83 \mu \mathrm{mol} / \mathrm{g}\left(\mathrm{Q}_{\mathrm{L} 1}=225\right.$ $\mu \mathrm{mol} / \mathrm{g}$ ). These values (reported in Table 2) are consistent with those obtained with the triangular $\Theta$ matrix in method M1 and lead to the theoretical (eq. (11)) curve e in Fig. 3 overlapping the experimental data (standard deviation: $\mathrm{S} . \mathrm{D}=0.9$ ).

\begin{tabular}{|c|c|c|c|c|c|c|}
\hline \multirow[t]{2}{*}{ Solids } & \multicolumn{2}{|c|}{$\begin{array}{c}\text { Brønsted acid sites } \\
\mu \mathrm{mol} / \mathrm{g}\end{array}$} & \multicolumn{2}{|c|}{$\begin{array}{c}\text { Lewis acid sites } \\
\mu \mathrm{mol} / \mathrm{g}\end{array}$} & \multirow[t]{2}{*}{$\begin{array}{c}\mathrm{Q}_{\mathrm{NH} 3}(300, \\
0.5 \mathrm{kPa})\end{array}$} & \multirow[t]{2}{*}{ S.D } \\
\hline & B1 & B2 & L1 & $\mathrm{L} 2$ & & \\
\hline $\mathrm{TiO}_{2}-\mathrm{P} 25$ & & & $\begin{array}{l}225 \\
233 \\
216\end{array}$ & $\begin{array}{c}83 \\
86^{*} \\
80^{*}\end{array}$ & $\begin{array}{l}330 \\
334 \\
338\end{array}$ & $\begin{array}{l}0.9 \\
1.3 \\
1.3\end{array}$ \\
\hline $6 \% \mathrm{WO}_{3} / \mathrm{TiO}_{2}-\mathrm{P} 25$ & $\begin{array}{c}12 \\
5 \\
30\end{array}$ & $\begin{array}{c}8 \\
3^{*} \\
20^{*}\end{array}$ & $\begin{array}{l}230 \\
238 \\
210\end{array}$ & $\begin{array}{c}124 \\
128 * \\
113 *\end{array}$ & $\begin{array}{l}374 \\
374 \\
373\end{array}$ & $\begin{array}{l}0.8 \\
0.8 \\
1.2\end{array}$ \\
\hline $\begin{array}{c}0.7 \% \mathrm{~V}_{2} \mathrm{O} / 9 \% \\
\mathrm{WO}_{3} / \mathrm{TiO}_{2}\end{array}$ & $\begin{array}{l}130 \\
108 \\
145\end{array}$ & $\begin{array}{c}70 \\
58^{*} \\
78^{*}\end{array}$ & $\begin{array}{l}202 \\
223 \\
186\end{array}$ & $\begin{array}{c}109 \\
120 * \\
100 *\end{array}$ & $\begin{array}{c}503 \\
509 \\
509\end{array}$ & $\begin{array}{l}1.5 \\
6.8 \\
4.5\end{array}$ \\
\hline
\end{tabular}

\# Standard deviation 
* Highest and lowest values leading to theoretical curves $\mathrm{Q}_{\mathrm{NH} 3}\left(\mathrm{~T}_{\mathrm{a}}, 0.5 \mathrm{kPa}\right)$ consistent with the experimental data (curve a in Fig. 3).

Table 2: Individual amount of acid sites on $\mathrm{TiO}_{2}$-based solids from eq. (11) using the total amount of $\mathrm{NH}_{3}$ adsorbed at the adsorption equilibrium for $\mathrm{T}_{\mathrm{a}} \geq 300 \mathrm{~K}$ and $\mathrm{P}_{\mathrm{a}} \approx 0.5 \mathrm{kPa}$ and an optimization function.

It must be noted that accepting a small increase in S.D such as from 0.9 to 1.3 , theoretical curves consistent with the experimental data can be obtained with other $\mathrm{Q}_{\mathrm{B}}$ and $\mathrm{Q}_{\mathrm{L} 2}$ values: QL2 cannot be strongly different that $83 \mu \mathrm{mol} / \mathrm{g}$, however small variations of QL2 lead to a significant modification of $\mathrm{Q}_{\mathrm{B}}$ (the higher is $\mathrm{Q}_{\mathrm{L} 2}$ the lower is $\mathrm{Q}_{\mathrm{B}}$ ). For instance, $\mathrm{Q}_{\mathrm{L} 2}$ and $\mathrm{Q}_{\mathrm{B}}$ couples in the range $\left(\mathrm{Q}_{\mathrm{L} 2}=80 \mu \mathrm{mol} / \mathrm{g}\right.$ and $\left.\mathrm{Q}_{\mathrm{B}}=42 \mu \mathrm{mol} / \mathrm{g}\right)$ and $\left(\mathrm{Q}_{\mathrm{L} 2}=86 \mu \mathrm{mol} / \mathrm{g}\right.$ and $\mathrm{Q}_{\mathrm{B}}=15$ $\mu \mathrm{mol} / \mathrm{g}$ ) (see S.D in Table 2) give theoretical curves consistent with the experimental data considering the experimental uncertainties whereas $\mathrm{Q}_{\mathrm{L} 2}=70 \mu \mathrm{mol} / \mathrm{g}$ and $\mathrm{Q}_{\mathrm{B}}=90 \mu \mathrm{mol} / \mathrm{g}$ lead to curve $\mathrm{f}$ in Fig. 3 differing significantly of curve a. Finally, method M2, which can be used whatever the acidic properties of a solid, provides the amounts of the strong L2 acid sites on $\mathrm{TiO}_{2}-\mathrm{P} 25$ with a reasonable accuracy $(83 \pm \approx 3 \mu \mathrm{mol} / \mathrm{g})$ whereas the uncertainty on the weak BAS is significantly higher. This situation is encountered for the other $\mathrm{TiO}_{2}$-based solids: the accuracy on the strong acid sites is significantly higher than those on the weak acid sites.

\subsection{Individual amounts of the acid sites on $6 \% \mathrm{WO}_{3} / \mathrm{TiO}_{2}-\mathrm{P} 25$ using $\mathrm{NH}_{3}$}

The FTIR study of the adsorption of $\mathrm{NH}_{3}$ on the $6 \% \mathrm{WO}_{3} / \mathrm{TiO}_{2}-\mathrm{P} 25$ solid has been described in detail in a previous work [37] and the results of interests for the present study are shortly summarized to facilitate the identification of the different acid sites. Figure S3 compares in the range of $1700-1100 \mathrm{~cm}^{-1}$, the IR spectra after adsorption of $0.1 \% \mathrm{NH}_{3} / \mathrm{He}$ at $300 \mathrm{~K}$ on $6 \% \mathrm{WO}_{3} / \mathrm{TiO}_{2}-\mathrm{P} 25$ and $\mathrm{TiO}_{2}-\mathrm{P} 25$ using disks of similar weights. After deposition of the $\mathrm{WO}_{\mathrm{x}}$ groups there are (a) a strong IR band at $1198 \mathrm{~cm}^{-1}$ and a shoulder at $1280 \mathrm{~cm}^{-1}$ ascribed similarly to $\mathrm{TiO}_{2}-\mathrm{P} 25$ to the $\delta_{\mathrm{s}}$ vibration of two adsorbed $\mathrm{NH}_{3}$ species on $\mathrm{L} 1$ and L2 LAS named $\mathrm{NH}_{3 \text { ads-L1 }}$ and $\mathrm{NH}_{3 \text { ads-L2 }}$ respectively, (b) an IR band at $1602 \mathrm{~cm}^{-1}$ due to the $\delta_{\text {as }}$ 
vibration of the two $\mathrm{NH}_{3 \text { ads-L1 }}$ and $\mathrm{NH}_{3 \text { ads-L2 }}$ species and (c) a broad IR band at $1445 \mathrm{~cm}^{-1}$ and a shoulder at $1680 \mathrm{~cm}^{-1}$ are ascribed to the deformation vibrations of $\mathrm{NH}_{4}{ }^{+}$species. Moreover, it has been shown that the overtone IR band at $2013 \mathrm{~cm}^{-1}$ of the $\mathrm{W}=\mathrm{O}$ vibration of $\mathrm{WO}_{\mathrm{x}}$ species is strongly modified by the adsorption of $\mathrm{NH}_{3}$ showing that $\mathrm{WO}_{\mathrm{x}}$ are involved as adsorption sites [37]. Figure $\mathrm{S} 3$ shows that the $\mathrm{WO}_{\mathrm{x}}$ groups lead to (a) strong shifts to higher wavenumbers of the $\delta_{\mathrm{s}}$ IR bands of the $\mathrm{NH}_{3 \text { ads-L }}$ species which is consistent with different literature data [41-43] and with the view that this vibration is very sensitive to the nature and environment of the sites (the common $\delta_{\text {as }}$ IR band is slightly modified as compared to $\mathrm{TiO}_{2}-25$ ) and (b) the IR band of the $\mathrm{NH}_{4}{ }^{+}$species at $1445 \mathrm{~cm}^{-1}$ is significantly increased indicating that $\mathrm{WO}_{\mathrm{x}}$ species favor the BAS [41-43].

The evolutions of the IR bands of the two $\mathrm{NH}_{3 \text { ads-L1 }}$ and $\mathrm{NH}_{3 \text { ads-L2 }}$ species with the increase in $\mathrm{T}_{\mathrm{a}}$ in the range of $300-700 \mathrm{~K}$ are qualitatively similar to those on the $\mathrm{TiO}_{2}-\mathrm{P} 25$ support and their individual heats of adsorption and proportions according to the AEIR method [37] are reported in Table 1. Similarly, the AEIR method has been applied to the IR band of the $\mathrm{NH}_{4}{ }^{+}$at $1445 \mathrm{~cm}^{-1}$ at $300 \mathrm{~K}$ which decreases progressively with the increase in $\mathrm{T}_{\mathrm{a}}$. However, it is detected at $700 \mathrm{~K}$ using $0.1 \% \mathrm{NH}_{3} / \mathrm{He}$ [37] indicating that the $\mathrm{WO}_{\mathrm{x}}$ groups are associated with strong BAS consistent with literature data [44-46]. It has been shown [37] that two $\mathrm{NH}_{4}^{+}$ species, named $\mathrm{NH}_{4}{ }^{+}-\mathrm{B} 1$ and $\mathrm{NH}_{4}{ }^{+}-\mathrm{B} 2$, formed on B1 and B2 BAS (1 and 2 in the increasing order of strength) contribute to the evolution of the intensity of the IR band with the increase in $\mathrm{T}_{\mathrm{a}}$ for $\mathrm{P}_{\mathrm{a}}=0.1 \mathrm{kPa}$. Their individual heats of adsorption and proportions are provided in Table 1 [37]. Finally, the FTIR study of the adsorption of $\mathrm{NH}_{3}$ on $6 \% \mathrm{WO}_{3} / \mathrm{TiO}_{2}$ leads to the conclusions that two LAS and two BAS are involved in the $\mathrm{NH}_{3}$ adsorption at $300 \mathrm{~K}$ and eq. (1) becomes:

$\mathrm{QTNH}_{3}\left(\mathrm{~T}_{\mathrm{a}}, \mathrm{P}_{\mathrm{a}}\right)=\mathrm{Q}_{\mathrm{L} 1} \theta_{\mathrm{NH} 3 \mathrm{ads}-\mathrm{L} 1}\left(\mathrm{~T}_{\mathrm{a}}, \mathrm{P}_{\mathrm{a}}\right)+\mathrm{Q}_{\mathrm{L} 2} \theta_{\mathrm{NH} 3 \mathrm{ads}-\mathrm{L} 2}\left(\mathrm{~T}_{\mathrm{a}}, \mathrm{P}_{\mathrm{a}}\right)+\mathrm{QB}_{\mathrm{B} 1} \theta_{\mathrm{NH} 4}{ }^{+}{ }_{-\mathrm{B} 1}\left(\mathrm{~T}_{\mathrm{a}}, \mathrm{P}_{\mathrm{a}}\right)+\mathrm{Q}_{\mathrm{B} 2} \theta_{\mathrm{NH}}{ }^{+}{ }_{-\mathrm{B} 2}\left(\mathrm{~T}_{\mathrm{a}}, \mathrm{P}_{\mathrm{a}}\right)(12)$ 
Figure 4 shows the evolution of the molar fractions of the gases during the switch $\mathrm{He}$ $\left(\right.$ Part A) $\rightarrow 0.5 \% \quad \mathrm{NH}_{3} / 0.5 \% \quad \mathrm{Ar} / \mathrm{He}(\mathrm{Part} \mathrm{B})$ on the pretreated $6 \% \quad \mathrm{WO}_{3} / \mathrm{TiO}_{2}-\mathrm{P} 25$ solid indicating that $\mathrm{QTNH}_{3}(300 \mathrm{~K}, 0.5 \mathrm{kPa}) \approx 373 \mu \mathrm{mol}$ of $\mathrm{NH}_{3} / \mathrm{g}$. The increase in $\mathrm{T}_{\mathrm{a}}$ (Fig. 3 Part C) leads to a net $\mathrm{NH}_{3}$ desorption rate due to the decrease in the coverages of the four adsorbed $\mathrm{NH}_{3}$ species according to a broad peak with a maximum at $362 \mathrm{~K}$. At $\mathrm{T}_{\mathrm{a}}>590 \mathrm{~K}$ there are productions of $\mathrm{H}_{2} \mathrm{O}$ and $\mathrm{N}_{2}$ which increase with $\mathrm{T}_{\mathrm{a}}$ associated with a net $\mathrm{NH}_{3}$ consumption at $\mathrm{T}_{\mathrm{a}}>680 \mathrm{~K}$. This indicates that at high temperatures and similarly to $\mathrm{V}_{2} \mathrm{O}_{5} / \mathrm{TiO}_{2}$ solids $[20,21]$ there is an oxidation of $\mathrm{NH}_{3}$ via oxygen species $\left(\mathrm{O}_{\mathrm{S}}\right)$ provided by the solid according to:

$$
2 \mathrm{NH}_{3}+3 \mathrm{O}_{\mathrm{S}} \rightarrow \mathrm{N}_{2}+3 \mathrm{H}_{2} \mathrm{O}
$$

Considering the absence of $\mathrm{N}_{2}$ production on $\mathrm{TiO}_{2}-\mathrm{P} 25$ (Fig. 2), the $\mathrm{O}_{\mathrm{s}}$ species must originate from the $\mathrm{WO}_{\mathrm{x}}$ species.

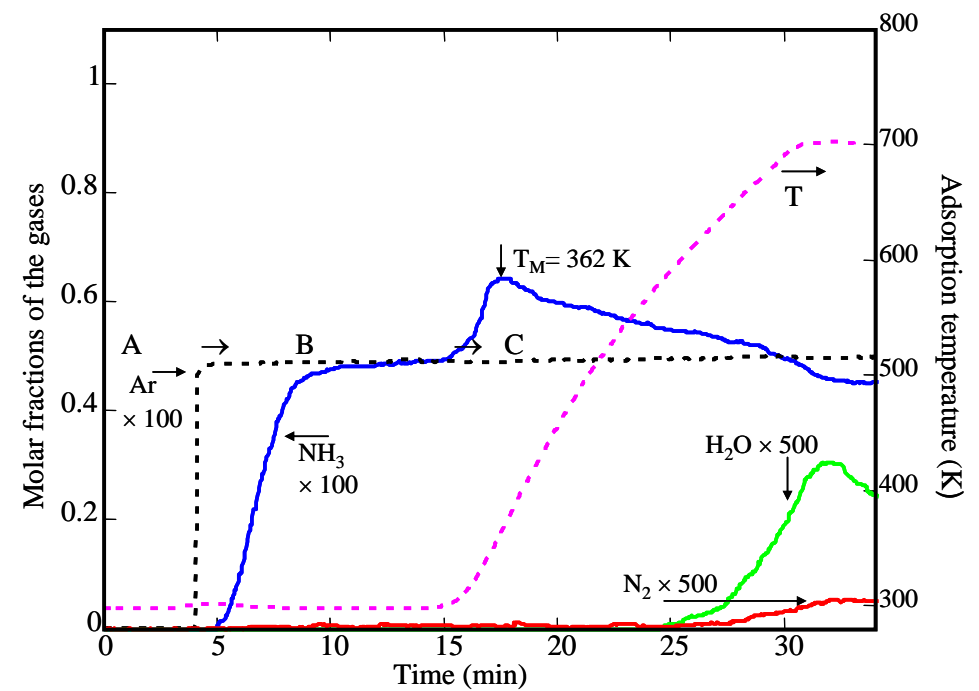

Figure 4: Adsorption of $\mathrm{NH}_{3}$ on the pretreated $6 \% \mathrm{WO}_{3} / \mathrm{TiO}_{2}-\mathrm{P} 25$ solid at different temperatures using the M.S system: Part A in Helium and Part B in $0.5 \% \mathrm{NH}_{3} / 0.5 \% \mathrm{Ar} / \mathrm{He}$ at $300 \mathrm{~K}$ : Part $\mathrm{C}$ increase in $\mathrm{T}_{\mathrm{a}}$ from 300 to $700 \mathrm{~K}$ (TPAE procedure).

The consumption of $\mathrm{NH}_{3}$ implies that $\mathrm{QTNH}_{3}\left(\mathrm{~T}_{\mathrm{a}}, \mathrm{P}_{\mathrm{a}}\right)$ must be measured at $\mathrm{T}_{\mathrm{a}}<590 \mathrm{~K}$ to prevent the contribution of the $\mathrm{NH}_{3}$ oxidation. Curve a in Fig. 5 shows the experimental evolution of $\mathrm{QTNH}_{3}\left(\mathrm{~T}_{\mathrm{a}}, \approx 0.5 \mathrm{kPa}\right)$ in the $300-590 \mathrm{~K}$ range from Part $\mathrm{C}$ in Fig. 4 (eqs (4) and (5)). Curves (b), (c), (d) and (e) in Fig. 5 give the evolutions of the coverages of the $\mathrm{NH}_{3 \text { ads-L1, }}$ $\mathrm{NH}_{4}{ }^{+}-\mathrm{B} 1, \mathrm{NH}_{4}{ }^{+}-\mathrm{B} 2$ and $\mathrm{NH}_{3 a d s-L 2}$ species respectively from eq ES1-ES2 and the data in Table 
1. These curves show that the four adsorbed species are present on the surface for $T_{a} \leq 590 \mathrm{~K}$ and that method M2 based on an optimization function must be used for the measurement of their individual amounts. Similarly to $\mathrm{TiO}_{2}-\mathrm{P} 25$, the number of variables is decreased before calculation by using the ratios $\mathrm{Q}_{\mathrm{L} 2} / \mathrm{Q}_{\mathrm{L} 1}=0.65 / 0.35$ and $\mathrm{Q}_{\mathrm{B} 2} / \mathrm{Q}_{\mathrm{B} 1}=0.6 / 0.4$ (Table 1 ) provided by the AEIR method leading from eq (12) to:

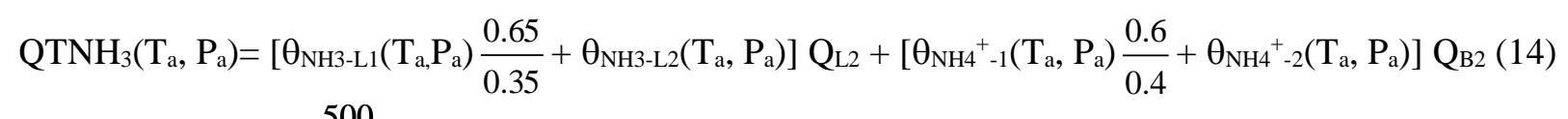

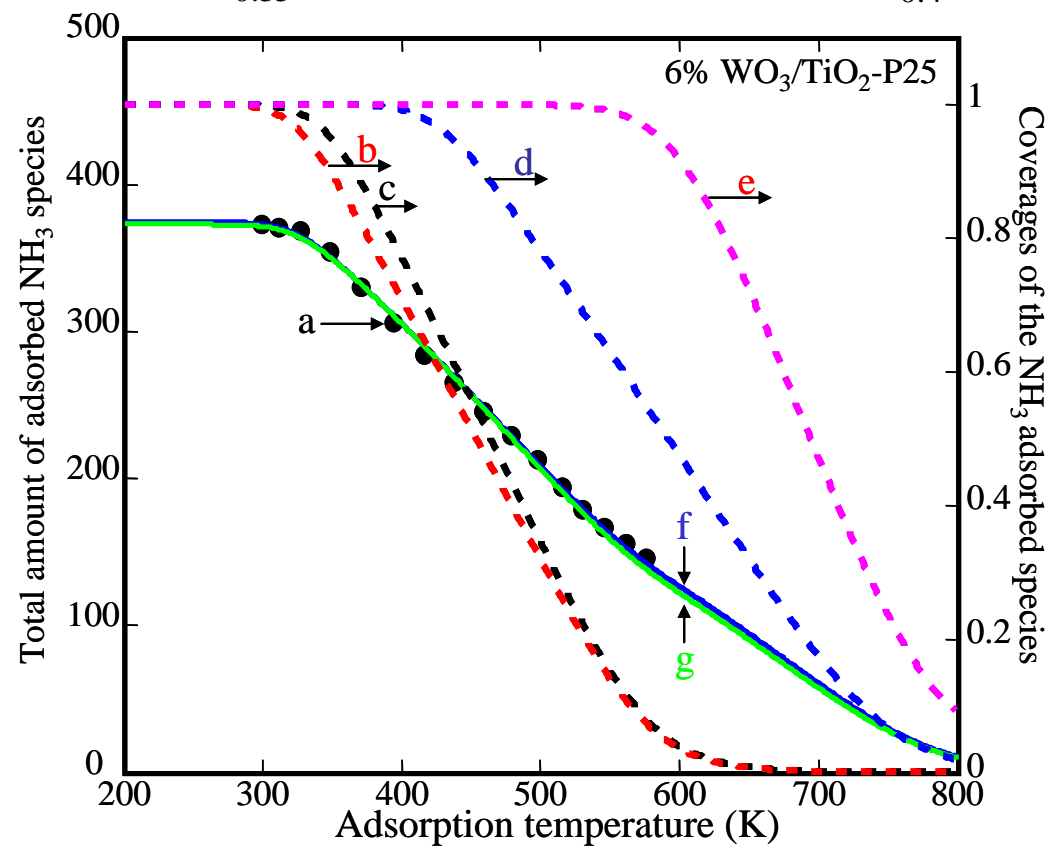

Figure 5: Total amount of $\mathrm{NH}_{3}$ adsorbed and coverage of the adsorbed $\mathrm{NH}_{3}$ species on $6 \%$ $\mathrm{WO}_{3} / \mathrm{TiO}_{2}$ at different adsorption temperatures $\mathrm{T}_{\mathrm{a}}$ : (a) experimental amount for $\mathrm{NH}_{3}$ from part $\mathrm{C}$ in Fig.4; (b), (c), (d) and (e) coverages of the $\mathrm{NH}_{3 \text { ads-L1 }}, \mathrm{NH}_{4}{ }^{+}-\mathrm{B} 1, \mathrm{NH}_{4}{ }^{+}-\mathrm{B} 2$ and $\mathrm{NH}_{3 \text { ads-L2 }}$ species respectively for $\mathrm{P}_{\mathrm{a}}=0.5 \mathrm{kPa}$; (f) theoretical total amount of $\mathrm{NH}_{3}$ adsorbed considering $\mathrm{Q}_{\mathrm{B} 2}=8.1 \mu \mathrm{mol} / \mathrm{g}, \mathrm{Q}_{2}=123.9 \mu \mathrm{mol} / \mathrm{g}$; $(\mathrm{g})$ theoretical total of $\mathrm{NH}_{3}$ adsorbed considering $\mathrm{Q}_{\mathrm{B} 2=}$ $20 \mu \mathrm{mol} / \mathrm{g}, \mathrm{Q}_{\mathrm{L} 1}=113 \mu \mathrm{mol} / \mathrm{g}\left(\mathrm{Q}_{\mathrm{B} 1}=30 \mu \mathrm{mol} / \mathrm{g}, \mathrm{Q}_{\mathrm{L} 1}=210 \mu \mathrm{mol} / \mathrm{g}\right)$.

The optimization function using eq. (14) provides $\mathrm{Q}_{\mathrm{L} 2}=123 \mu \mathrm{mol} / \mathrm{g}$ and $\mathrm{Q}_{\mathrm{B} 2}=8 \mu \mathrm{mol} / \mathrm{g}$ leading to curve $\mathrm{f}$ in Fig. 5 which overlaps the experimental curve a in (standard deviation: $\mathrm{S} . \mathrm{D}=0.8$ ). However, similarly to $\mathrm{TiO}_{2}-\mathrm{P} 25$, accepting an increase in S.D, others $\mathrm{Q}_{\mathrm{L} 2}$ and $\mathrm{Q}_{\mathrm{B} 2}$ values can be consistent with the experimental data. For instance curve $g$ is obtained using $\mathrm{Q}_{\mathrm{L} 2}=113 \mu \mathrm{mol} / \mathrm{g}$ and $\mathrm{Q}_{\mathrm{B} 2}=20 \mu \mathrm{mol} / \mathrm{g}$ (standard deviation of 1.23) (lower $\mathrm{Q}_{\mathrm{L} 2}$ values lead to theoretical curves significantly different of curve a in the high $\mathrm{T}_{\mathrm{a}}$ range). Note that $\mathrm{Q}_{\mathrm{L} 2}$ cannot 
by significantly higher than $123 \mu \mathrm{mol} / \mathrm{g}$ because this leads to negative $\mathrm{Q}_{\mathrm{B} 2}$ values. Table 2 summarizes the $\mathrm{Q}_{\mathrm{B} 1}, \mathrm{Q}_{\mathrm{B} 2}, \mathrm{Q}_{\mathrm{L} 1}$ and $\mathrm{Q}_{\mathrm{L} 2}$ values obtained from the optimization function and the highest and lowest values leading from eq. (14) to a theoretical curve consistent with curve a accepting a small increase in S.D.

\subsection{Individual amounts of the acid sites on $\mathrm{V}_{2} \mathrm{O}_{5} / \mathrm{WO}_{3} / \mathrm{TiO}_{2}$ using $\mathrm{NH}_{3}$}

Raman and IR spectroscopy have shown that $\mathrm{V}$ and $\mathrm{W}$ of this $\mathrm{NH}_{3}-\mathrm{SCR}$ catalyst are present as well dispersed mono-oxo $\mathrm{VO}_{\mathrm{x}}$ and $\mathrm{WO}_{\mathrm{y}}$ groups [37]. Similarly to $6 \% \mathrm{WO}_{3} / \mathrm{TiO}_{2}$, four adsorbed $\mathrm{NH}_{3}$ species are formed on the $\mathrm{NH}_{3}-\mathrm{SCR}$ catalyst for $\mathrm{T}_{\mathrm{a}}=300 \mathrm{~K}$ and $\mathrm{P}_{\mathrm{a}}=0.5 \mathrm{kPa}$, on two LAS (L1 and L2) and two BAS (B1 and B2) and their individual heats of adsorption and proportions have been determined using the AEIR method (Table 1) [38].

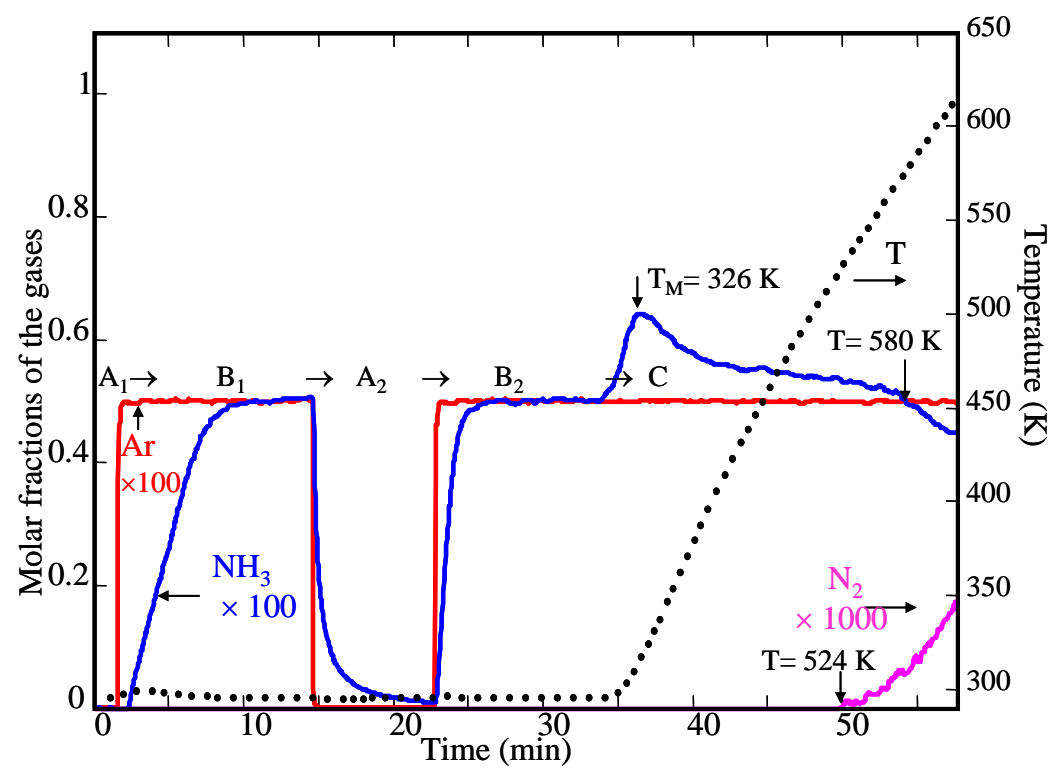

Figure 6: Adsorption of $\mathrm{NH}_{3}$ on the pretreated sulfated $0.7 \% \mathrm{~V}_{2} \mathrm{O}_{5} / 9 \% \mathrm{WO}_{3} / \mathrm{TiO}_{2}$ catalyst at different temperatures using the M.S system: Parts $A_{1}, A_{2}$ in Helium and Parts $B_{1}, B_{2}$ in $0.5 \%$ $\mathrm{NH}_{3} / 0.5 \%$ Ar/He at $300 \mathrm{~K}$; Part C increase in $\mathrm{T}_{\mathrm{a}}$ from 300 to $700 \mathrm{~K}$ (TPAE procedure).

For this solid, the individual amounts of acid sites present a particular interest taking into account that $\mathrm{NH}_{3}$ is one of the reactant of the $\mathrm{NH}_{3}-\mathrm{SCR}$ reaction and that there is a debate on the nature of the acid site (either BAS or LAS) involved in its activation by adsorption [4751]. Figure 6 shows the evolution of the molar fractions of $\mathrm{NH}_{3}$ and $\mathrm{Ar}$ at the microreactor 
outlet during the switch $\mathrm{He}\left(\operatorname{Part} \mathrm{A}_{1}\right) \rightarrow 0.5 \% \mathrm{NH}_{3} / 0.5 \% \mathrm{Ar} / \mathrm{He}\left(\operatorname{Part} \mathrm{B}_{1}\right)$ at $300 \mathrm{~K}$ on the pretreated $0.7 \% \mathrm{~V}_{2} \mathrm{O}_{5} / 9 \% \mathrm{WO}_{3} / \mathrm{TiO}_{2}$ catalyst leading from eq. (3) to $\mathrm{QTNH}_{3}(300 \mathrm{~K}, 0.5 \mathrm{kPa})=$ $502 \mu \mathrm{mol} / \mathrm{g}$. This amount exceeds significantly the total amount of mono-oxo species: $\approx 77$ $\mu \mathrm{mol}$ of $\mathrm{VO}_{\mathrm{x}} / \mathrm{g}$ and $\approx 388 \mu \mathrm{mol}$ of $\mathrm{WO}_{\mathrm{y}} / \mathrm{g}$ indicating that some acid sites are located on the $\mathrm{TiO}_{2}$ support in agreement with Busca et al. [52] and with the densities $2.9 \mathrm{~W} / \mathrm{nm}^{2}$ and 0.6 $\mathrm{V} / \mathrm{nm}^{2}$ in the catalyst which are lower than the accepted values for a monolayer $\approx 4.5 \mathrm{~W} / \mathrm{nm}^{2}$ and $8 \mathrm{~V} / \mathrm{nm}^{2}$ [48]. The switch $0.5 \% \mathrm{NH}_{3} / 0.5 \% \mathrm{Ar} / \mathrm{He} \rightarrow \mathrm{He}$ (Figure 6, part $\mathrm{A}_{2}$ ), shows the desorption of $130 \mu \mathrm{mol}$ of $\mathrm{NH}_{3} / \mathrm{g}$ (readsorbed in Part $\mathrm{B}_{2}$ during the switch $\mathrm{He} \rightarrow 0.5 \%$ $\mathrm{NH}_{3} / 0.5 \% \mathrm{Ar} / \mathrm{He}$ ) due to $\mathrm{NH}_{3}$ species having low heats of adsorption at full coverage (mainly $\mathrm{NH}_{3}$ ads-L1 and $\mathrm{NH}_{4}{ }^{+}-\mathrm{B} 1$, see Table 1). Part $\mathrm{C}$ in Fig. 6 gives the evolutions of the molar fractions of the gases during the linear increase in $\mathrm{T}_{\mathrm{a}}$ in the presence of $0.5 \% \mathrm{NH}_{3} / 0.5 \% \mathrm{Ar} / \mathrm{He}$. A broad $\mathrm{NH}_{3}$ peak is observed with a maximum at $\mathrm{T}_{\mathrm{m}}=326 \mathrm{~K}$ due to the progressive decrease in the coverage of the four adsorbed species. There is production of $\mathrm{N}_{2}$ (with $\mathrm{H}_{2} \mathrm{O}$, not shown) for $\mathrm{T}_{\mathrm{a}}>520 \mathrm{~K}$, indicating that a fraction of $\mathrm{NH}_{3}$ is oxidized by $\mathrm{O}_{\mathrm{S}}$ species of the catalyst and for $\mathrm{T}_{\mathrm{a}}>580 \mathrm{~K}$, this oxidation leads to a net consumption of $\mathrm{NH}_{3}$. This indicates that the measurements of $\mathrm{QTNH}_{3}\left(\mathrm{~T}_{\mathrm{a}}, \mathrm{P}_{\mathrm{a}}\right)$ must be performed at $\mathrm{T}_{\mathrm{a}}<\approx 520 \mathrm{~K}$.

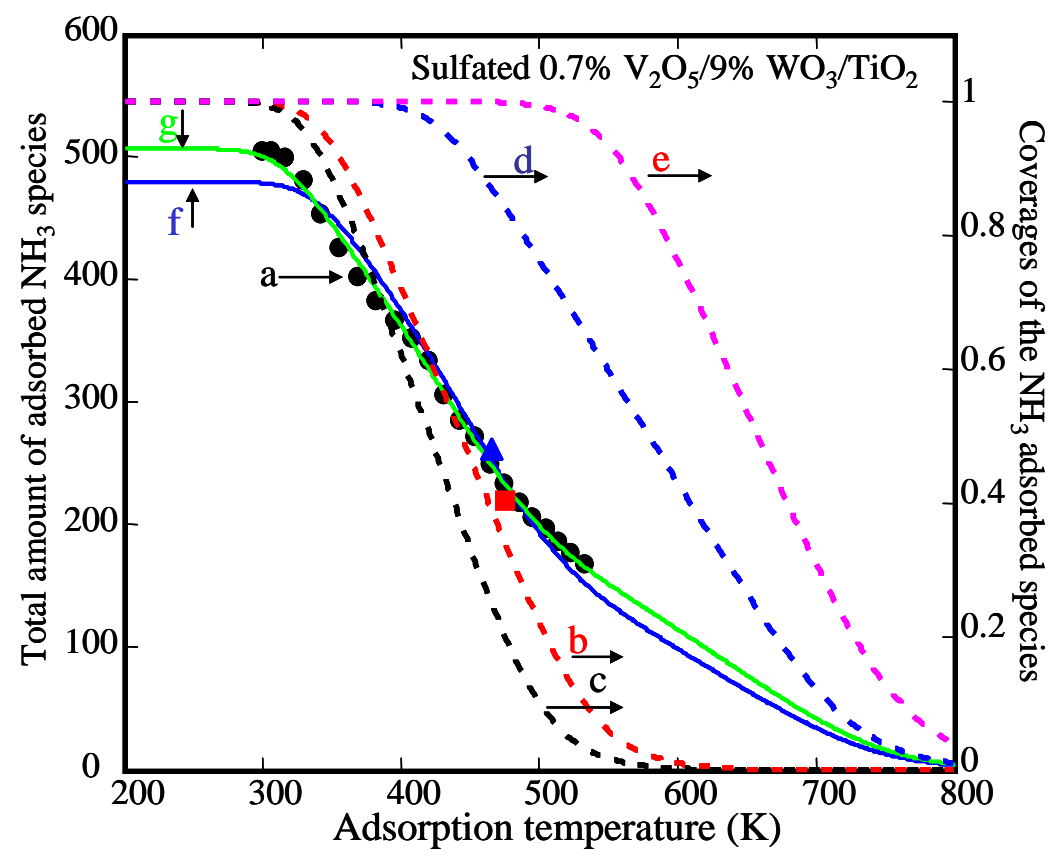


Figure 7: Total amount of $\mathrm{NH}_{3}$ adsorbed and coverage of the adsorbed $\mathrm{NH}_{3}$ species on $0.7 \%$ $\mathrm{V}_{2} \mathrm{O}_{5} / 9 \% \mathrm{WO}_{3} / \mathrm{TiO}_{2}$ at different adsorption temperatures $\mathrm{T}_{\mathrm{a}}$ : (a) experimental amount for $\mathrm{NH}_{3}$ from part C in Fig. 6 ( $\boldsymbol{\Delta}, \mathbf{\square}$ measurements similarly to part $\mathrm{B}_{1}$ of Fig. 6 at $464 \mathrm{~K}$ and $480 \mathrm{~K}$ ); (b), (c), (d) and (e) coverages of the $\mathrm{NH}_{4}{ }^{+}-\mathrm{B} 1, \mathrm{NH}_{3 \text { ads-L1 }}, \mathrm{NH}_{4}{ }^{+}-\mathrm{B} 2$ and $\mathrm{NH}_{3 \text { ads-L2 }}$ species respectively for $\mathrm{P}_{\mathrm{a}}=0.5 \mathrm{kPa}$; (f) theoretical total amount of $\mathrm{NH}_{3}$ adsorbed considering the heats of adsorption in Table 1 with $\mathrm{Q}_{\mathrm{B} 2}=95 \mu \mathrm{mol} / \mathrm{g}$, $\mathrm{Q}_{\mathrm{L} 2}=73 \mu \mathrm{mol} / \mathrm{g}(\mathrm{S} . \mathrm{D}=3.8)$; (g) theoretical total amount of $\mathrm{NH}_{3}$ adsorbed after a slight decrease in the heats of adsorption of the two weakly adsorbed $\mathrm{NH}_{3}$ species: $\mathrm{E}(0)=95 \mathrm{~kJ} / \mathrm{mol}$ and $\mathrm{E}(1)=54 \mathrm{~kJ} / \mathrm{mol}$ for $\mathrm{NH}_{3 \text { ads-L1 }}$ species and $\mathrm{E}(0)=85$ $\mathrm{kJ} / \mathrm{mol}$ and $\mathrm{E}(1)=52 \mathrm{~kJ} / \mathrm{mol}$ for $\mathrm{NH}_{4}{ }^{+}-\mathrm{B} 1$ with $\mathrm{Q}_{\mathrm{B} 2}=70 \mu \mathrm{mol} / \mathrm{g}, \mathrm{Q}_{\mathrm{L} 2}=109 \mu \mathrm{mol} / \mathrm{g}(\mathrm{S} . \mathrm{D}=1.5)$. (see the text for more details).

Curve a in Fig. 7 shows the experimental evolution of $\mathrm{QTNH}_{3}\left(\mathrm{~T}_{\mathrm{a}}, \approx 0.5 \mathrm{kPa}\right)$ (eqs (4), (5)) from Part $C$ in Fig. 6 in the $T_{a}$ range 300-520 K. Curves (b), (c), (d) and (e) in Fig. 7 give the evolutions of the coverages of the $\mathrm{NH}_{4}{ }^{+}-\mathrm{B} 1, \mathrm{NH}_{3 \text { ads-L1 }}, \mathrm{NH}_{4}{ }^{+}-\mathrm{B} 2$ and $\mathrm{NH}_{3 \text { ads-L2 }}$ species respectively from eq ES1-ES2 and the data in Table 1. These curves show that the four adsorbed species contribute to the adsorption of $\mathrm{NH}_{3}$ in the $\mathrm{T}_{\mathrm{a}}$ range of curve a and that method M2 must be used for the measurement of the amount of each acid site. Similarly to $\mathrm{TiO}_{2}-\mathrm{P} 25$ and $6 \% \mathrm{WO}_{3} / \mathrm{TiO}_{2}-\mathrm{P} 25$, the number of variables is decreased by using the ratios $\mathrm{Q}_{\mathrm{L} 2} / \mathrm{Q}_{\mathrm{L} 1}=$ 0.65/0.35 and $\mathrm{Q}_{\mathrm{B} 2} / \mathrm{Q}_{\mathrm{B} 1}=0.65 / 0.35$ (Table 1 ) leading from eq (1) to:

$\mathrm{QTNH}_{3}\left(\mathrm{~T}_{\mathrm{a}}, \mathrm{P}_{\mathrm{a}}\right)=\left[\theta_{\mathrm{NH} 3-\mathrm{L} 1}\left(\mathrm{~T}_{\mathrm{a}}, \mathrm{P}_{\mathrm{a}}\right) \frac{0.65}{0.35}+\theta_{\mathrm{NH} 3-\mathrm{L} 2}\left(\mathrm{~T}_{\mathrm{a}}, \mathrm{P}_{\mathrm{a}}\right)\right] \mathrm{Q}_{\mathrm{L} 2}+\left[\theta_{\mathrm{NH} 4}{ }^{+}-\mathrm{B} 1\left(\mathrm{~T}_{\mathrm{a}}, \mathrm{P}_{\mathrm{a}}\right) \frac{0.65}{0.35}+\theta_{\mathrm{NH} 4^{+}-\mathrm{B} 2}\left(\mathrm{~T}_{\mathrm{a}}, \mathrm{P}_{\mathrm{a}}\right)\right] \mathrm{Q}_{\mathrm{B} 2}(15)$ Using eqs ES1-ES2 and Table 1, the optimization function provides $\mathrm{Q}_{\mathrm{L} 2} \approx 73 \mu \mathrm{mol} / \mathrm{g}$ and $\mathrm{Q}_{\mathrm{B} 2=}$ $95 \mu \mathrm{mol} / \mathrm{g}$ leading to curve $\mathrm{f}$ in Fig. 7 (S.D = 3.8). This curve is consistent with the experimental data in the high adsorption temperatures range whereas a significant difference is observed for $\mathrm{T}_{\mathrm{a}}<341 \mathrm{~K}$ (at $\mathrm{T}_{\mathrm{a}}=300 \mathrm{~K}$ the theoretical amount of adsorbed $\mathrm{NH}_{3}$ species is $\approx 480$ $\mu \mathrm{mol} / \mathrm{g}$ as compared to $502 \mu \mathrm{mol} / \mathrm{g}$ in curve a in Fig. 7). This seems due to the impacts of the uncertainties on the heats of adsorption of the weakly adsorbed $\mathrm{NH}_{3 \text { ads-L1 }}$ and $\mathrm{NH}_{4}{ }^{+}-\mathrm{B} 1$ species. For instance, a decrease by an amount equal or lower than the uncertainty of the AEIR method $( \pm 5 \mathrm{~kJ} / \mathrm{mol})$ of the heats of adsorption of the $\mathrm{NH}_{3 a d s-\mathrm{L} 1}$ and $\mathrm{NH}_{4}{ }^{+}-\mathrm{B} 1$ species leads from the 
optimization function to $\mathrm{Q}_{\mathrm{B} 2}=70 \mu \mathrm{mol} / \mathrm{g}\left(\mathrm{Q}_{\mathrm{B} 1}=130 \mu \mathrm{mol} / \mathrm{g}\right)$ and $\mathrm{Q}_{\mathrm{L} 2}=109 \mu \mathrm{mol} / \mathrm{g}\left(\mathrm{Q}_{\mathrm{L} 1}=202\right.$ $\mu \mathrm{mol} / \mathrm{g}$ ) and then to curve $\mathrm{g}$ in Fig. 7 which overlaps the experimental data in the full $\mathrm{T}_{\mathrm{a}}$ range $(\mathrm{S} . \mathrm{D}=1.5)$. Others values of $\mathrm{Q}_{\mathrm{B} 2}$ and $\mathrm{Q}_{\mathrm{L} 2}$ gives theoretical curves consistent with the experimental data accepting a slight increase in S.D: there are in the range $100-120 \mu \mathrm{mol} / \mathrm{g}$ for $\mathrm{Q}_{\mathrm{L} 2}$ corresponding to 78-58 for $\mathrm{Q}_{\mathrm{B} 2}$ (see Table 2).

After the experiments in Fig. 6, the catalyst sample has been pretreated at $713 \mathrm{~K}$ and the total amount of $\mathrm{NH}_{3}$ has been measured at $464 \mathrm{~K}$ using $0.5 \% \mathrm{NH}_{3} / 0.5 \% \mathrm{Ar} / \mathrm{He}$ similarly to part B1 in Fig. 6 (symbol $\boldsymbol{\Delta}$ in Fig. 7). Then after a new pretreatment at $713 \mathrm{~K}$, a similar measurement has been performed at $480 \mathrm{~K}$ (symbol $\boldsymbol{\square}$ in Fig. 7). The overlap of symbols

and $\mathbf{\text { in Fig. }} 7$ with curve a shows the repeatability of the experiments and the limited impact of the successive pretreatments on the adsorption capacity of the solid. To our knowledge, there are no literature data on the individual amount of LAS and BAS on a $\mathrm{V}_{2} \mathrm{O}_{5} / \mathrm{WO}_{3} / \mathrm{TiO}_{2}$ $\mathrm{NH}_{3}-\mathrm{SCR}$ catalyst to be compared with the present study. However, eq. (15) and the data in Tables 1 and 2 allow us determining the total amount of $\mathrm{NH}_{3}$ adsorbed at the adsorption equilibrium whatever $\mathrm{T}_{\mathrm{a}}$ and $\mathrm{P}_{\mathrm{a}}$. This permits comparison with literature data on $\mathrm{NH}_{3}-\mathrm{SCR}$ catalysts having a composition similar to the present catalyst. For instance, Lietti et al. [53, 54] have determined 270 moles of $\mathrm{NH}_{3} / \mathrm{m}^{3}$ of catalyst at $493 \mathrm{~K}$ on a $1.4 \% \mathrm{~V}_{2} \mathrm{O}_{5} / 9 \%$ $\mathrm{WO}_{3} / \mathrm{TiO}_{2}$ catalyst (BET surface area similar to the present study: $80 \mathrm{~m}^{2} / \mathrm{g}$ ) using $700 \mathrm{ppm}$ $\mathrm{NH}_{3} / 1 \% \mathrm{O}_{2} / \mathrm{He}$. Equation (15) provides $\mathrm{QTNH}_{3}(493 \mathrm{~K}, 700 \mathrm{~Pa})=217 \mu \mathrm{mol} / \mathrm{g}$ using the heats of adsorption of the adsorbed species leading to curve $\mathrm{g}$ in Fig. 7 corresponding to $\approx 304$ moles of $\mathrm{NH}_{3} / \mathrm{m}^{3}$ (the density of the present catalyst is $\approx 1.4 \mathrm{~g} / \mathrm{cm}^{3}$ ) in reasonable agreement with Lietti et al. $[53,54]$ considering the differences in the solid composition and preparation methods. Similarly, Xie et al. [55] on a commercial $1.15 \% \quad \mathrm{~V}_{2} \mathrm{O}_{5} / 2.84 \% \mathrm{WO}_{3} / \mathrm{TiO}_{2}$ catalyst (BET surface area $46.5 \mathrm{~m}^{2} / \mathrm{g}$ ) have determined $\approx 233$ moles of $\mathrm{NH}_{3} / \mathrm{m}^{3}$ for $\mathrm{P}_{\mathrm{NH} 3}=400 \mathrm{~Pa}$ and 
$\mathrm{T}_{\mathrm{a}}=493 \mathrm{~K}$ while eq 15 provides $\mathrm{QTNH}_{3}(493 \mathrm{~K}, 400 \mathrm{~Pa})=202 \mu \mathrm{mol} / \mathrm{g}$ and then $283 \mathrm{~mol} / \mathrm{m}^{3}$. The difference is consistent with the BET surface area.

The measurement of the individual amount of acid sites is of particular interest for solids involved in catalytic reactions. For instance, after the identification of the active acid sites, the rate of the reaction can be expressed in TOF $\left(\mathrm{s}^{-1}\right)$ and compared to the theoretical reaction rate obtained from kinetic model supported by an experimental microkinetic approach. Moreover, these data can be used for the understanding of the surface processes involved a catalytic reaction. For instance, it is shown below that the individual amounts of the acid sites on the $0.7 \% \mathrm{~V}_{2} \mathrm{O}_{5} / 9 \% \mathrm{WO}_{3} / \mathrm{TiO}_{2}$ catalyst (Table 2) permit performing nitrogen mass balances in relationship with the production of $\mathrm{N}_{2}$ via the reaction of $\mathrm{NO}$ with the adsorbed $\mathrm{NH}_{3}$ species leading to the identifications of (a) the acid site and (b) the pivotal adsorbed $\mathrm{NH}_{3}$ species involved in the $\mathrm{NH}_{3}-\mathrm{SCR}$ reaction.

\subsection{Nature of the acid sites involved in the $\mathrm{NH}_{3}-\mathrm{SCR}$ reaction on $\mathrm{V}_{2} \mathrm{O}_{5}-\mathrm{WO}_{3}-\mathrm{TiO}_{2}$}

It is known $[21,56]$ that adsorbed $\mathrm{NH}_{3}$ species on $\mathrm{V}_{2} \mathrm{O}_{5}-\mathrm{WO}_{3}-\mathrm{TiO}_{2}$ may react at $\mathrm{T}_{\mathrm{a}}>$ $400 \mathrm{~K}$ with $\mathrm{NO}$ in the absence of $\mathrm{O}_{2}$ via lattice oxygen species provided by the solid according to the global reaction:

$$
2 \mathrm{NH}_{3 \mathrm{ads}}+2 \mathrm{NO}+\mathrm{O}_{1} \rightarrow 2 \mathrm{~N}_{2}+3 \mathrm{H}_{2} \mathrm{O}
$$

The elementary steps of this reaction are parts of those of the $\mathrm{NH}_{3}-\mathrm{SCR}$ reaction according to [4]:

$$
4 \mathrm{NH}_{3 \mathrm{ads}}+4 \mathrm{NO}+\mathrm{O}_{2} \rightarrow 4 \mathrm{~N}_{2}+6 \mathrm{H}_{2} \mathrm{O}
$$

This means that the identification $\mathrm{NH}_{3 \text { ads }}$ in eq. (16) may provide that of the pivotal species of the $\mathrm{NH}_{3}-\mathrm{SCR}$ reaction. This can be performed by studying reaction (16) according to an experimental microkinetic approach based on transient experiments with the M.S system and working on the relationship between the individual amount of each adsorbed $\mathrm{NH}_{3}$ species before reaction and the amount of $\mathrm{N}_{2}$ production. For instance, Fig. 8 provides the amount of 
adsorbed $\mathrm{NH}_{3}$ species at $464 \mathrm{~K}$ on the pretreated solid according to the switch $\mathrm{He}$ (part $\mathrm{A}_{1}$ ) $\rightarrow$ $0.5 \% \mathrm{NH}_{3} / 0.5 \% \mathrm{Ar} / \mathrm{He}$ (part $\mathrm{B}_{1}$ ): $261 \mu \mathrm{mol}$ of $\mathrm{NH}_{3} / \mathrm{g}$. This values is consistent taking into account the experimental uncertainties with the theoretical amounts of each adsorbed $\mathrm{NH}_{3}$ species at $\mathrm{T}_{\mathrm{a}}=464 \mathrm{~K}$ and $\mathrm{P}_{\mathrm{a}}=0.5 \mathrm{kPa}$ considering the data to obtain curve $\mathrm{g}$ in Fig. 7: 109, 60, 64 and $17 \mu \mathrm{mol} / \mathrm{g}$ for the $\mathrm{NH}_{3 \text { ads-L2}}, \mathrm{NH}_{4}{ }^{+}-\mathrm{B} 2, \mathrm{NH}_{3 \text { ads-L1 }}$ and $\mathrm{NH}_{4}{ }^{+}-\mathrm{B} 1$ species respectively (theoretical total amount $\left.\mathrm{QTNH}_{3}(464 \mathrm{~K}, 0.5 \mathrm{kPa})=250 \mu \mathrm{mol} / \mathrm{g}\right)$. These data are reported in line 2 of Table 3. The switch $0.5 \% \mathrm{NH}_{3} / 0.5 \% \mathrm{Ar} / \mathrm{He}\left(\right.$ part $\left.\mathrm{B}_{1}\right) \rightarrow \mathrm{He}\left(\right.$ part $\mathrm{A}_{2}$ ) in Fig. 8 indicates the desorption of $98 \mu \mathrm{mol} / \mathrm{g}$ of $\mathrm{NH}_{3}$ after $\approx 6 \mathrm{~min}$ in helium leading to $163 \mu \mathrm{mol} / \mathrm{g}$ of adsorbed $\mathrm{NH}_{3}$ species (reported in Table 3 line 3 column 2). Neglecting the $\mathrm{NH}_{3}$ readsorption during desorption then calculations similar to Fig. ES2 indicate that only the $\mathrm{NH}_{3 \text { ads-L2 }}$ can be present on the surface after $6 \mathrm{~min}$ in helium at $464 \mathrm{~K}$, with a theoretical coverage $\approx 0.07$ corresponding to $\approx 8 \mu \mathrm{mol}$ of $\mathrm{NH}_{3} / \mathrm{g}$.

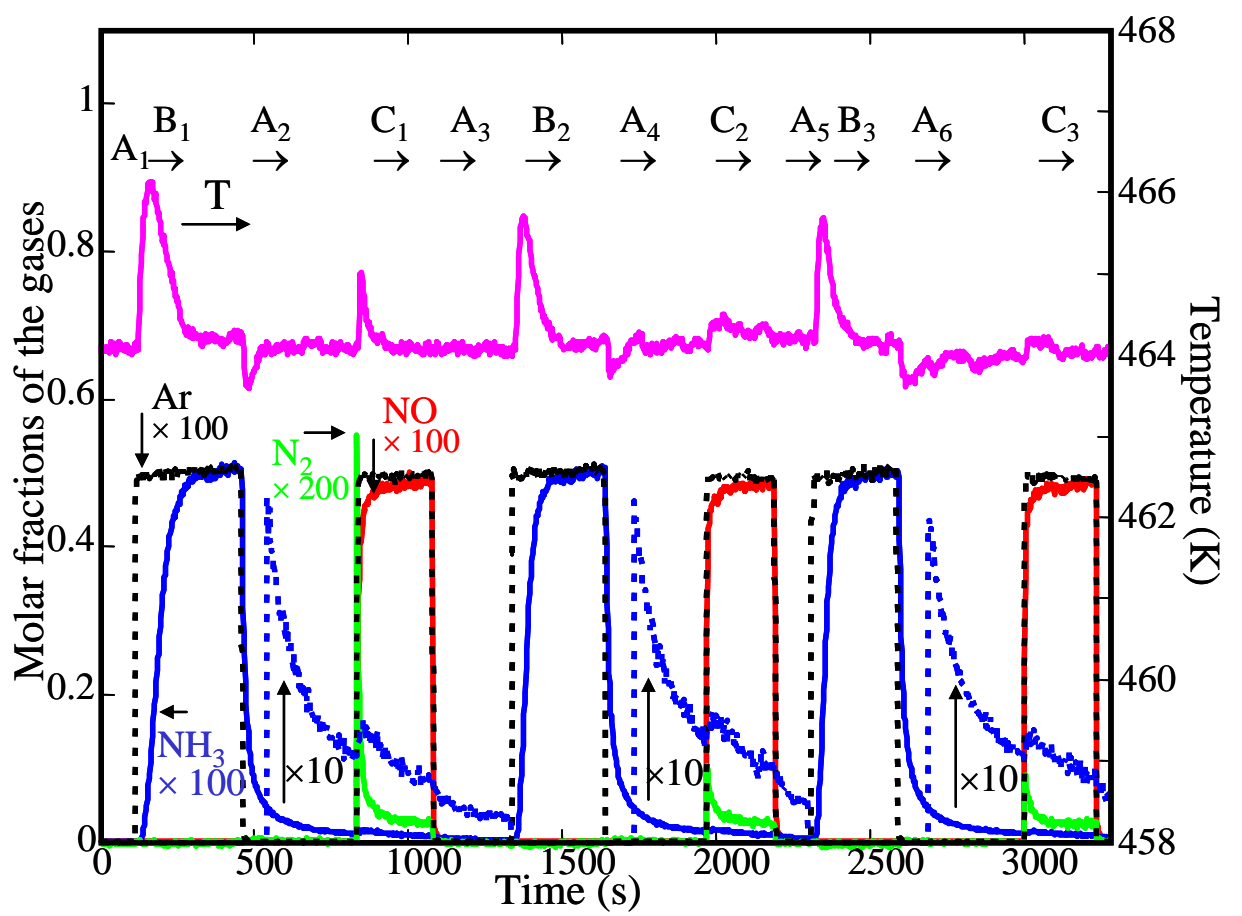

Figure 8: Isothermal reaction at $464 \mathrm{~K}$ between adsorbed $\mathrm{NH}_{3}$ species and $\mathrm{NO}$ from transient experiments using successive switches between gas flow rates: $A_{x}$ in helium, $B_{x}$ in $0.5 \%$ $\mathrm{NH}_{3} / 0.5 \% \mathrm{Ar} / \mathrm{He}$ and $\mathrm{C}_{\mathrm{x}}$ in $0.5 \% \mathrm{NO} / 0.5 \% \mathrm{Ar} / \mathrm{He}$.

This amount is strongly smaller than the experimental data, confirming that $\mathrm{NH}_{3}$ readsorption cannot be neglected in the interpretation of desorption experiments in agreement 
with literature data $[14,16,29]$. In part $\mathrm{A}_{2}$ of Fig. 8, the coverages of the different $\mathrm{NH}_{3}$ species evolve as a succession of adsorption equilibriums with the decrease in $\mathrm{P}_{\mathrm{NH} 3}$. For instance, in Fig. 8 at the end of part $\mathrm{A}_{2}, \mathrm{P}_{\mathrm{NH} 3} \approx 12 \mathrm{~Pa}$ and $\mathrm{T}_{\mathrm{a}}=464 \mathrm{~K}$, then eq 15 and the data used for curve $\mathrm{g}$ in Fig. 7 provide $\mathrm{QTNH}_{3}(464 \mathrm{~K}, 12 \mathrm{~Pa})=160 \mu \mathrm{mol} / \mathrm{g}$ which is consistent with the experimental data (the individual amounts of the four adsorbed species are indicated in Table 3 line 3). In Fig 8, the switch $\mathrm{He}\left(\right.$ part $\left.\mathrm{A}_{2}\right) \rightarrow 0.5 \% \mathrm{NO} / 0.5 \% \mathrm{Ar} / \mathrm{He}\left(\right.$ part $\mathrm{C}_{1}$ ) leads to a sharp $\mathrm{N}_{2}$ production peak during $\approx 70 \mathrm{~s}$ followed by a pseudo steady state indicating that reaction eq. (16) is operant. The total $\mathrm{N}_{2}$ production in part $\mathrm{C}_{1}$ is $\mathrm{Q}_{\mathrm{N} 2}=45 \mu \mathrm{mol} / \mathrm{g}$ in parallel to a $\mathrm{NO}$ consumption of $\mathrm{Q}_{\mathrm{NO}}=43 \mu \mathrm{mol} / \mathrm{g}$. The ratio $\mathrm{Q}_{\mathrm{NO}} / \mathrm{Q}_{\mathrm{N} 2} \approx 1$ is consistent with the stoichiometry of reaction eq. (16).

\begin{tabular}{|c|c|c|c|c|c|c|}
\hline \multirow[t]{2}{*}{$\begin{array}{l}\text { Experiment } \\
\text { At } 464 \mathrm{~K}\end{array}$} & $\mathrm{QTNH}_{3}(\exp )$ & $\begin{array}{c}\mathrm{QTNH}_{3}(\text { theo }) \\
\text { eq } 15\end{array}$ & $\mathrm{Q}_{\mathrm{NH3}}$ ads-L2 & $Q_{\text {NH3ads-L1 }}$ & $\mathrm{Q}_{\mathrm{NH} 4+-2}$ & $\mathrm{Q}_{\mathrm{NH} 4+-1}$ \\
\hline & \multicolumn{6}{|c|}{$\mu \mathrm{mol} \mathrm{NH} \mathrm{NH}_{3} / \mathrm{g}$ of catalyst } \\
\hline $\begin{array}{c}\text { Adsorption } \mathrm{NH}_{3} \\
\mathrm{P}_{\mathrm{NH}_{3}}=500 \mathrm{~Pa} \\
\text { part } \mathrm{B}_{1}\end{array}$ & 261 & 250 & 109 & 64 & 60 & 17 \\
\hline $\begin{array}{c}\text { Desorption: } 6 \mathrm{~min} \\
\mathrm{P}_{\mathrm{NH} 3}=12 \mathrm{~Pa} \\
\text { end part } \mathrm{A}_{2}\end{array}$ & 163 & 160 & 105 & 10 & 44 & 1 \\
\hline $\begin{array}{c}\text { NO reaction: } 4 \text { min } \\
P_{\mathrm{NH} 3}=7 \mathrm{~Pa} \\
\text { end part } \mathrm{C}_{1}\end{array}$ & 105 & 151 & 103 & 6 & 42 & 0 \\
\hline
\end{tabular}

* the difference with $\mathrm{Q}_{\mathrm{NH} 3 \mathrm{~T}}(\mathrm{exp})$ comes from the consumption of the $\mathrm{NH}_{3 \text { ads-L2 }}$ species in the presence of NO.

Table 3: Experimental and theoretical (from eq 15) total amounts of adsorbed $\mathrm{NH}_{3}$ species on $0.7 \% \mathrm{~V}_{2} \mathrm{O}_{5} / 9 \% \mathrm{WO}_{3} / \mathrm{TiO}_{2}$ catalyst at $464 \mathrm{~K}$ during the experiments in Fig. 8 and contribution of the different adsorbed $\mathrm{NH}_{3}$ species to $\mathrm{QTNH}_{3}($ theo).

Note that (a) $\mathrm{NH}_{3}$ desorption continues in parallel to the $\mathrm{N}_{2}$ production: $\approx 13 \mu$ mol of $\mathrm{NH}_{3} / \mathrm{g}$ and $\mathrm{P}_{\mathrm{NH}_{3}} \approx 7 \mathrm{~Pa}$ at the end of part $\mathrm{C}_{1}$, (b) the transient increase in the sample temperature associated with the $\mathrm{N}_{2}$ peak is consistent with the $\Delta \mathrm{H}$ of the $\mathrm{NH}_{3}-\mathrm{SCR}$ reaction: $-407 \mathrm{~kJ} / \mathrm{mol}$ [57] and explains the slight increase in the net $\mathrm{NH}_{3}$ desorption rate at the introduction of $\mathrm{NO}$ and (c) $\mathrm{H}_{2} \mathrm{O}$ is produced (not shown) together with $\mathrm{N}_{2}$, however its production cannot be related to the stoichiometry of eq 16 due to its adsorption on the catalyst. The pseudo steady 
state of the $\mathrm{N}_{2}$ production in part $\mathrm{C}_{1}$ of Fig. 8 comes from the progressive decrease in the rate of the reaction (eq 16) with the consumptions of (a) the adsorbed intermediate $\mathrm{NH}_{3 \text { ads }}$ species and (b) the lattice oxygen species $\mathrm{O}_{1}$. Moreover, as $\mathrm{Q}_{\mathrm{NO}} \approx \mathrm{Q}_{\mathrm{N} 2}$ there is no significant adsorption of $\mathrm{NO}$ in the presence of the adsorbed $\mathrm{NH}_{3}$ species consistently with the Eley-Rideal mechanism used in numerous kinetic studies of the $\mathrm{NH}_{3}-\mathrm{SCR}$ on $\mathrm{V}_{2} \mathrm{O}_{5}-\mathrm{WO}_{3}-\mathrm{TiO}_{2}$ catalysts $[5$, 47, 49, 58-62]. The desorption of $\mathrm{NH}_{3}$ continues after the switch $0.5 \% \mathrm{NO} / 0.5 \% \mathrm{Ar} / \mathrm{He}$ (part $\left.\mathrm{C}_{1}\right) \rightarrow \mathrm{He}\left(\right.$ part $\left.\mathrm{A}_{3}\right): \approx 7 \mu \mathrm{mol} / \mathrm{g}$, leading to $\mathrm{P}_{\mathrm{NH} 3} \approx 4 \mathrm{~Pa}$ at the end of part $\mathrm{A}_{3}$, indicating that adsorbed $\mathrm{NH}_{3}$ species are present on the catalyst at the pseudo steady state of part $\mathrm{C}_{1}$. This is consistent with the high heats of adsorption of the $\mathrm{NH}_{3 \text { ads-L2 }}$ and $\mathrm{NH}_{4}{ }^{+}-\mathrm{B} 2$ species which allow maintaining significant coverages for low adsorption pressures such a 0.64 and 0.34 respectively at $\mathrm{T}_{\mathrm{a}}=464 \mathrm{~K}$ and $\mathrm{P}_{\mathrm{a}}=0.1 \mathrm{~Pa}$ ( $\mathrm{P}_{\mathrm{NH} 3}$ must be $\leq 10^{-5} \mathrm{~Pa}$ to obtain an adsorption equilibrium coverage of $\approx 0$ at $464 \mathrm{~K}$ for $\mathrm{NH}_{3 \text { ads-L2 }}$ species).

Nitrogen mass balances considering (a) the individual amounts of the four adsorbed $\mathrm{NH}_{3}$ species at the end of part $\mathrm{A}_{2}$ in Fig. 8 (line 3 Table 3) and (b) the $\mathrm{N}_{2}$ production in part $\mathrm{C}_{1}$ permit the identification of the $\mathrm{NH}_{3}$ ads species in reaction (16). The stoichiometry of eq. (16) indicates that the $\mathrm{N}_{2}$ production: $45 \mu \mathrm{mol}$ of $\mathrm{N}_{2} / \mathrm{g}$ consumes the same amount of $\mathrm{NH}_{3 \text { ads }}$ species: this species can be neither $\mathrm{NH}_{3 \text { ads-L1 }}$ nor $\mathrm{NH}_{4}{ }^{+}$-B1 which are present in amounts $<45 \mu \mathrm{mol} / \mathrm{g}$ at the introduction of NO (Table 3 line 3). Moreover, the pseudo steady state of the $\mathrm{N}_{2}$ production in part $\mathrm{C}_{1}$ indicates that a significant amount of the $\mathrm{NH}_{3 \text { ads }}$ involved in reaction (16) must be present at the end of part $\mathrm{C}_{1}$. This fact (a) does not correspond to the $\mathrm{NH}_{4}{ }^{+}-\mathrm{B} 2$ species because the $\mathrm{N}_{2}$ production in part $\mathrm{C}_{1}\left(45 \mu \mathrm{mol} \mathrm{N} \mathrm{N}_{2} / \mathrm{g}\right)$ represents the total amount of this species before introduction of NO (Table 3, line 3, column 6) and (b) is consistent with the $\mathrm{NH}_{3 \text { ads-L2 }}$ species: the $\mathrm{N}_{2}$ production in part $\mathrm{C}_{1}$ represents $\approx 43 \%$ of its amount before introduction of NO. The conclusion that $\mathrm{NH}_{3 \text { ads-L2 }}$ species is the species involved in eq. (16) is reinforced taking into account the desorption of $\mathrm{NH}_{3}$ in parallel to the $\mathrm{N}_{2}$ production: $\approx 13 \mu \mathrm{mol} / \mathrm{g}$. In Fig. 8, the $\mathrm{N}_{2}$ 
and $\mathrm{NH}_{3}$ productions in part $\mathrm{C}_{1}$ indicate that $\approx 58 \mu \mathrm{mol}$ of $\mathrm{NH}_{3} / \mathrm{g}$ have been removed from the surface leading to $163-58=105 \mu \mathrm{mol} / \mathrm{g}$ of adsorbed $\mathrm{NH}_{3}$ species whereas $\mathrm{P}_{\mathrm{NH} 3} \approx 7 \mathrm{~Pa}$ before the switch $\mathrm{C}_{1} \rightarrow \mathrm{A}_{3}$. The theoretical amounts of the four adsorbed $\mathrm{NH}_{3}$ species at $\mathrm{T}_{\mathrm{a}}=464 \mathrm{~K}$ and $\mathrm{P}_{\mathrm{a}}=7 \mathrm{~Pa}$ are indicated in Table 3 (line 4) leading to $\mathrm{QTNH}_{3}(464 \mathrm{~K}, 7 \mathrm{~Pa})=151 \mu \mathrm{mol} / \mathrm{g}$ which is higher than the experimental data: $105 \mu \mathrm{mol} / \mathrm{g}$, due to the consumption of the $\mathrm{NH}_{3 a d s-}$ L2 species for the $\mathrm{N}_{2}$ production in the presence of NO. However, in Table 3, the theoretical decrease in the amounts of adsorbed $\mathrm{NH}_{3}$ species due to the decrease in $\mathrm{P}_{\mathrm{a}}$ from $12 \mathrm{~Pa}$ (line 3 ) to $7 \mathrm{~Pa}$ (line 4): $9 \mu \mathrm{mol} / \mathrm{g}$, is consistent taking into account the accuracy of the measurements with the experimental $\mathrm{NH}_{3}$ desorption in part $\mathrm{C}_{1}: 13 \mu \mathrm{mol} / \mathrm{g}$. Finally, in part $\mathrm{C}_{1}$ of Fig. 8, the $\mathrm{NH}_{3}$ production comes from the four adsorbed $\mathrm{NH}_{3}$ species (main contribution of the $\mathrm{NH}_{3 \text { ads-L1 }}$ ) whereas the $\mathrm{N}_{2}$ production is due to the reaction of $\mathrm{NO}$ with the $\mathrm{NH}_{3 \text { ads-L2 }}$ species (eq. (16)). This conclusion constitutes a contribution to the debate on the nature of the acid site/adsorbed $\mathrm{NH}_{3}$ species which is active in the $\mathrm{NH}_{3}-\mathrm{SCR}$ on $\mathrm{V}_{2} \mathrm{O}_{5}-\mathrm{WO}_{3}-\mathrm{TiO}_{2}$ catalyst and confirms recent works $[48,49]$ (and references therein) showing the key role of LAS in the reaction. However, Lai and Wachs [49] conclude that the surface vanadia species, in the $\mathrm{V}^{+5}$ oxidation state are the catalytic active sites for the $\mathrm{SCR}$ reaction on $\mathrm{V}_{2} \mathrm{O}_{5}-\mathrm{WO}_{3}-\mathrm{TiO}_{2}$ catalyst while the surface tungsta species $\left(\mathrm{W}^{+6}\right)$ are not active for the SCR reaction (or less active than $\mathrm{V}^{+5}[48]$ ) but promote the surface vanadia species. The present measurements shows that the situation is more complex considering that the amount of L2 sites involved in the reaction (16) on the $\mathrm{NH}_{3}-\mathrm{SCR}$ catalyst: $109 \mu \mathrm{mol} / \mathrm{g}$ is higher than the amount of $\mathrm{V}$ in the solid: $77 \mu \mathrm{mol} / \mathrm{g}$ indicating a contribution of a fraction of the $\mathrm{W}^{+6}$ sites.

The above $\mathrm{N}$ mass balances revealing the role of the $\mathrm{NH}_{3 \text { ads-L2 }}$ species as pivotal species of the $\mathrm{NH}_{3}$-SCR via eq. 16 are validated and completed by the adsorption of $\mathrm{NH}_{3}$ after the reaction with $\mathrm{NO}$ has shown in part $\mathrm{B} 2$ of Fig. 8. The switch $0.5 \% \mathrm{NO} / 0.5 \% \mathrm{Ar} / \mathrm{He}\left(\right.$ part $\left._{1}\right) \rightarrow$ $\mathrm{He}$ (part $\mathrm{A}_{3}$ ) indicate the desorption of $7 \mu \mathrm{mol}$ of $\mathrm{NH}_{3} / \mathrm{g}$ leading to an experimental total 
amount of adsorbed $\mathrm{NH}_{3}$ species of $105-7=98 \mu \mathrm{mol} / \mathrm{g}$. The switch $\mathrm{He}$ (part $\mathrm{A}_{3}$ ) $\rightarrow 0.5 \%$ $\mathrm{NH}_{3} / 0.5 \% \mathrm{Ar} / \mathrm{He}$ (part $\mathrm{B}_{2}$ ) leads to the adsorption of $163 \mu \mathrm{mol}$ of $\mathrm{NH}_{3} / \mathrm{g}$. This amount is lower than in part $\mathrm{B}_{1}$ confirming the presence of adsorbed $\mathrm{NH}_{3}$ species in part $\mathrm{A}_{3}$. The total amount of adsorbed $\mathrm{NH}_{3}$ species at the adsorption equilibrium in part $\mathrm{B}_{2}: \approx 163+98=261 \mu \mathrm{mol} / \mathrm{g}$ is similar to that on the pretreated solid $(273 \mu \mathrm{mol} / \mathrm{g}$, Table 3 , line 2$)$. The difference is maybe due to the adsorption of $\mathrm{H}_{2} \mathrm{O}$ produced in part $\mathrm{C}_{1}$ which may change the proportion of LAS and BAS [63]. After the switch $0.5 \% \mathrm{NH}_{3} / 0.5 \% \mathrm{Ar} / \mathrm{He} \rightarrow \mathrm{He}$ (Fig. 8, part $\mathrm{A}_{4}$ ) leading to the desorption of $121 \mu \mathrm{mol}$ of $\mathrm{NH}_{3} / \mathrm{g}$, the introduction of $0.5 \% \mathrm{NO} / 0.5 \% \mathrm{Ar} / \mathrm{He}\left(\mathrm{Part}_{2}\right)$ leads to a $\mathrm{N}_{2}$ production: $31 \mu \mathrm{mol} / \mathrm{g}$, without the sharp peak observed in part $\mathrm{C}_{1}$, associated with a NO consumption of $32 \mu \mathrm{mol} / \mathrm{g}$ while $18 \mu \mathrm{mol}$ of $\mathrm{NH}_{3} / \mathrm{g}$ desorb. The higher $\mathrm{N}_{2}$ production rate at the introduction of $\mathrm{NO}$ in part $\mathrm{C}_{2}$ than at the end of $\mathrm{C}_{1}$ comes from the increase in the amount of pivotal $\mathrm{NH}_{3}$ ads-L2 species by the $\mathrm{NH}_{3}$ adsorption. However, the $\mathrm{N}_{2}$ peak at the introduction of $\mathrm{NO}$ in part $\mathrm{C}_{2}$ is significantly smaller than in part $\mathrm{C}_{1}$ because of the lower amount of lattice $\mathrm{O}_{1}$ species in the solid. The experiments have been repeated in part $\mathrm{B}_{3}-\mathrm{C}_{3}$ leading to similar quantitative data with a progressive decrease in the $\mathrm{N}_{2}$ production rate due to the decrease in the amount of lattice $\mathrm{O}_{1}$ species in the solid.

\section{Conclusion}

The present study has been dedicated to the development of an original method using $\mathrm{NH}_{3}$ adsorption for the measurement of the individual amounts $\mathrm{Q}_{\mathrm{ASi}}$ of the different $\mathrm{AS}_{\mathrm{i}}$ acid sites present on three $\mathrm{TiO}_{2}$ based solids of increasing complexity: $\mathrm{TiO}_{2}-\mathrm{P} 25,6 \% \mathrm{WO}_{3} / \mathrm{TiO}_{2}-\mathrm{P} 25$ and sulfated $0.7 \% \mathrm{~V}_{2} \mathrm{O}_{5} / 9 \% \mathrm{WO}_{3} / \mathrm{TiO}_{2} \mathrm{NH}_{3}-\mathrm{SCR}$ catalyst. The method is based on the quantitative application of FTIR spectroscopy of adsorbed $\mathrm{NH}_{3}$ species according to the AEIR method [34] associated with volumetric measurements using a mass spectrometer. $\mathrm{TiO}_{2}-\mathrm{P} 25$ which is widely used either alone (i.e photocatalytic reactions) or as support for active phases has been 
used for the development of the method. FTIR spectroscopy indicates that $\mathrm{TiO}_{2}-\mathrm{P} 25$ has two types of LAS: L1 and L2, and one weak BAS consistent with literature data whereas the others solids have two types of LAS and two types of BAS named L1, L2, B1 and B2 (1 and 2 in the increasing order of strength). The heats of adsorption of the different adsorbed $\mathrm{NH}_{3}$ species on the three solids were known (Table 1) from the AEIR method [30, 37, 38]. This provides their adsorption equilibrium coverages on each of the $A S_{i}$ acid sites: $\theta_{N H 3 a d s-A S i}\left(T_{a}, P_{a}\right)$ whatever $T_{a}$ and $\mathrm{P}_{\mathrm{a}}$. The volumetric measurements give the total amount of adsorbed $\mathrm{NH}_{3}$ species for different adsorption equilibrium conditions at $\mathrm{T}_{\mathrm{a}}$ and $\mathrm{P}_{\mathrm{a}}$ : $\mathrm{QTNH}_{3}\left(\mathrm{~T}_{\mathrm{a}}, \mathrm{P}_{\mathrm{a}}\right)$ in $\mu \mathrm{mol} / \mathrm{g}$ which is equal to the sum of the contribution of each adsorbed species: $\mathrm{Q}_{\mathrm{ASi}} \theta_{\mathrm{NH} 3 \mathrm{ads}-\mathrm{ASi}}\left(\mathrm{T}_{\mathrm{a}}, \mathrm{P}_{\mathrm{a}}\right)$. The individual amounts $\mathrm{Q}_{\mathrm{ASi}}$ of $\mathrm{n} \mathrm{AS}_{\mathrm{i}}$ acid sites of a solid are obtained by numerical solutions of at least a $n$ linear equations system obtained for the measurements of $n \mathrm{QTNH}_{3}\left(\mathrm{~T}_{\mathrm{a}}, \mathrm{P}_{\mathrm{a}}\right)$ values: this is the situation for $\mathrm{TiO}_{2}-\mathrm{P} 25$. The others solids impose the measurements of a larger series of $\mathrm{QTNH}_{3}\left(\mathrm{~T}_{\mathrm{a}}, \mathrm{P}_{\mathrm{a}}\right)$ which is facilitated by using the TPAE method [35] which provides the experimental evolution $\mathrm{QTNH}_{3}\left(\mathrm{~T}_{\mathrm{a}}, \mathrm{P}_{\mathrm{a}}\right)=\mathrm{f}\left(\mathrm{T}_{\mathrm{a}}\right)$ in quasi isobaric conditions $\mathrm{P}_{\mathrm{a}}$. Then an optimization function gives the $\mathrm{Q}_{\mathrm{ASi}}$ values leading to the best agreement between the experimental and a theoretical $\mathrm{QTNH}_{3}\left(\mathrm{~T}_{\mathrm{a}}, \mathrm{P}_{\mathrm{a}}\right)$ curves: i.e the individual amounts (in $\mu \mathrm{mol} / \mathrm{g}$ ) of the acid sites on the pretreated sulfated $0.7 \% \mathrm{~V}_{2} \mathrm{O}_{5} / 9 \% \mathrm{WO}_{3} / \mathrm{TiO}_{2}$ solid are $109,202,70$ and 130 in $\mu \mathrm{mol} / \mathrm{g}$ for $\mathrm{Q}_{\mathrm{L} 2}, \mathrm{Q}_{\mathrm{L} 1}, \mathrm{Q}_{\mathrm{B} 2}$ and $\mathrm{Q}_{\mathrm{B} 1}$ respectively. The $\mathrm{Q}_{\mathrm{ASi}}$ values are of particular interest for solids used as catalysts such as $\mathrm{V}_{2} \mathrm{O}_{5} / \mathrm{WO}_{3} / \mathrm{TiO}_{2}$ for the removal of $\mathrm{NO}$ by the $\mathrm{NH}_{3}-\mathrm{SCR}$ reaction. For this solid we have shown how the amounts $\mathrm{Q}_{\mathrm{L} 2}, \mathrm{Q}_{\mathrm{L} 1}, \mathrm{Q}_{\mathrm{B} 2}$ and $\mathrm{Q}_{\mathrm{B} 1}$ permit the exploitation via $\mathrm{N}$ mass balances of transient experiments in relationship with the $\mathrm{NH}_{3}-\mathrm{SCR}$ reaction leading to the conclusion that the $\mathrm{L}_{2}$ acid site is the one forming the pivotal $\mathrm{NH}_{3 \text { ads-L2 }}$ species of the reaction.

\section{Appendix A. Supplementary data}

Supplementary data associated with this article can be found in the online version 


\section{References}

[1] F. Nakajima, I. Hamada, The State-of-the-art Technology of $\mathrm{NO}_{\mathrm{x}}$ Control. Catal. Today 29 (1996) 109-115

[2] X. Shang, J. Li, X. Yu, J. Chen, C. He, Effective Regeneration of Thermally Deactivated Commercial V-W-Ti Catalysts. Front. Chem. Sci. Eng. 6 (2012) 38-46.

[3] G. Busca, L. Lietti, G. Ramis, F. Berti, Chemical and Mechanistic Aspects of the Selective Catalytic Reduction of NOx by Ammonia over Oxide Catalysts: A review. Appl. Catal. B 18 (1998) 1-36.

[4] I. Nova, L. dall'Acqua, L. Lietti, E. Giamello, P. Forzatti, Study of Thermal Deactivation of a De-NOx Commercial Catalyst. Appl. Catal. B 35 (2001) 31-42.

[5] J.C. Vedrine, Importance, Features and Uses of Metal Oxide Catalysts in Heterogeneous Catalysis. Chinese J. Catal. 40 (2019) 1627-1636.

[6] J.A. Lercher, C. Griündling, G. Eder-Mirth, Infrared Studies of the Surface Acidity of Oxides and Zeolites using Adsorbed Probe Molecules. Catal. Today 27 (1996) 353-376.

[7] M. Boronat, A.Corma, What Is Measured When Measuring Acidity in Zeolites with Probe Molecules?. ACS Catal. 9 (2019) 1539-1548.

[8] G. Busca, Spectroscopic Characterization of the Acid Properties of Metal Oxide Catalysts. Catal. Today 41 (1998) 191-206.

[9] A. Zecchina, L. Marchese, S. Bordiga, C. Pazè, E. Gianotti, Vibrational Spectroscopy of $\mathrm{NH}_{4}^{+}$Ions in Zeolitic Materials: An IR Study. J. Phys. Chem. B, 101 (1997) 10128-10135

[10] G. Busca, H. Saussey, O. Saur, J.C. Lavalley, V. Lorenzelli, FTIR Characterization of Surface Acidity of Different Titanium Dioxide Anatase Preparation. Appl. Catal. 14 (1985) $245-260$.

[11] G. Ramis, G. Busca, V. Lorenzelli, P. Forzatti, Fourier Transform Infrared Study of the Adsorption and Coadsorption of Nitric Oxide, Nitrogen Dioxide and Ammonia on $\mathrm{TiO}_{2}$ Anatase. Appl. Catal. 64 (1990) 243-257.

[12] E. Guglielminotti, F. Boccuzzi, Infrared Spectroscopic Study of Ammonia and Nitric Oxide Adsorption and Reactivity on a Ru/TiO, Catalyst: Effect of Oxo-reducing Treatments. J. Chem. Soc. Faraday Trans. 87 (1991) 337-343.

[13] K. Hadjiivanov, D. Klissurski, G. Busca, V. Lorenzelli, Benzene-Ammonia Coadsorption on $\mathrm{TiO}_{2}$ (Anatase). J. Chem. Soc. Faraday Trans. 87 (1991) 175-178. 
[14] M. Niwa, N. Katada, New Method for the Temperature-Programmed Desorption (TPD) of Ammonia Experiment for Characterization of Zeolite Acidity: A Review. Chem. Rec. 13 (2013) 432-455.

[15] O. Bortnovsky, Z. Melichar, Z. Sobalík, B. Wichterlová, Quantitative Analysis of Aluminium and Iron in the Framework of Zeolites. Microporous Mesoporous Mater. 42 (2001) 97-102.

[16] K. Suzuki, T. Noda, N. Katada, M. Niwa, IRMS-TPD of Ammonia: Direct and Individual Measurement of Brønsted Acidity in Zeolites and its Relationship with the Catalytic Cracking Activity. J. Catal. 250 (2007) 151-164.

[17] A. Taouli, W. Reschetilowski, Comparative Study of MCM-41 Acidity by Using the Integrated Molar Extinction Coefficients for Infrared Absorption Bands of Adsorbed Ammonia. Stud. Surf. Sci. Catal. 142 (2002) 1315-1322.

[18] J.L. Falconer, J.A. Schwarz, Temperature-Programmed Desorption and Reaction: Applications to supported Catalysts. Catal. Rev. Sci. Eng. 25 (1983) 141-227.

[19] J.C Lemaitre, Temperature Programmed Methods, in Characterization of Heterogeneous Catalysts, Chap. 2, Marcel Dekker: New York, 1984.

[20] G.T. Went, L. Leu, S.J. Lombardo, A.T. Bell, Raman Spectroscopy and Thermal Desorption of $\mathrm{NH}_{3}$ Adsorbed on $\mathrm{TiO}_{2}$ (Anatase)-Supported $\mathrm{V}_{2} \mathrm{O}_{5}$. J. Phys. Chem. 96 (1992) 2235-2241.

[21] L. Lietti, P. Forzatti, Temperature Programmed Desorption/Reaction of Ammonia over $\mathrm{V}_{2} \mathrm{O}_{5} / \mathrm{TiO}_{2}$ De-NOxing Catalysts. J. Catal. 147 (1994) 241-249.

[22] T.Z. Srnak, J.A. Dumesic, B.S. Clausen, E. Tornqvist, N.Y. Topsøe, TemperatureProgrammed Desorption/Reaction and in Situ Spectroscopic Studies of Vanadia/Titania for Catalytic Reduction of Nitric Oxide. J. Catal. 135 (1992) 246-262.

[23] M. Turco, G. Bagnasco, G. Russo, P. Ciambelh, P. Patrono, M.A. Massucci, S. Vecchio, $\mathrm{NH}_{3}$ TPD Study and Thermal Behaviour of Vanadium-Exchanged Titanium Phosphates as Catalysis. Reduction of NO with $\mathrm{NH}_{3}$. J. Therm. Anal. 47 (1996) 215-225.

[24] S.T. Choo, Y.G. Lee, I.S. Nam, S.W. Ham, J.B. Lee, Characteristics of $\mathrm{V}_{2} \mathrm{O}_{5}$ Supported on Sulfated $\mathrm{TiO}_{2}$ for Selective Catalytic Reduction of $\mathrm{NO}$ by $\mathrm{NH}_{3}$. Appl. Catal. A 200 (2000) 177-188.

[25] S.S.R. Putluru, L. Schill, A. Godiksen, R. Poreddy, S. Mossin, A.D. Jensen, R. Fehrmann, Promoted $\mathrm{V}_{2} \mathrm{O}_{5} / \mathrm{TiO}_{2}$ Catalysts for Selective Catalytic Reduction of NO with $\mathrm{NH}_{3}$ at Low Temperatures. Appl. Catal. B 183 (2016) 282-290. 
[26] I. Song, S. Youn, H. Lee, S.G. Lee, S.J. Cho, D.H. Kim, Effects of Microporous $\mathrm{TiO}_{2}$ Support on the Catalytic and Structural Properties of $\mathrm{V}_{2} \mathrm{O}_{5} /$ Microporous $\mathrm{TiO}_{2}$ for the Selective Catalytic Reduction of NO by $\mathrm{NH}_{3}$. Appl. Catal. B 210 (2017) 421-431.

[27] R. Ning, L. Chen, E. Li, X. Liu, T. Zhu, Applicability of $\mathrm{V}_{2} \mathrm{O}_{5}-\mathrm{WO}_{3} / \mathrm{TiO}_{2}$ Catalysts for the SCR Denitrification of Alumina Calcining Flue Gas. Catalysts 9 (2019) 220-231.

[28] X. Liu, H. Chen, X. Wu, L. Cao, P. Jiang, Q. Yu, Y. Ma, Effects of $\mathrm{SiO}_{2}$ Modification on the Hydrothermal Stability of the $\mathrm{V}_{2} \mathrm{O}_{5} / \mathrm{WO}_{3}-\mathrm{TiO}_{2} \mathrm{NH}_{3}-\mathrm{SCR}$ Catalyst: $\mathrm{TiO}_{2}$ Structure and Vanadia Species. Catal. Sci. Technol. 9 (2019) 3711-3720.

[29] R.A. Demmin, R.J. Gorte, Design Parameters for Temperature-Programmed Desorption from a Packed Bed. J. Catal. 90 (1984) 32-39.

[30] F. Giraud, C. Geantet, N. Guilhaume, S. Gros, L. Porcheron, M. Kanniche, D. Bianchi, Experimental Microkinetic Approach of De- $\mathrm{NO}_{\mathrm{x}}$ by $\mathrm{NH}_{3}$ on $\mathrm{V}_{2} \mathrm{O}_{5} / \mathrm{WO}_{2} / \mathrm{TiO}_{2}$ Catalysts: 1Individual Heats of Adsorption of Adsorbed $\mathrm{NH}_{3}$ species on a Sulfate-free $\mathrm{TiO}_{2}$ Support using adsorption isobars. J. Phys. Chem. C 118 (2014) 15664-15676.

[31] Y. Xu, X. Wu, Q. Lin, J. Hu, R. Ran, D. Weng, $\mathrm{SO}_{2}$ Promoted $\mathrm{V}_{2} \mathrm{O}_{5}-\mathrm{MoO}_{3} / \mathrm{TiO}_{2}$ Catalyst for $\mathrm{NH}_{3}-\mathrm{SCR}$ of NOx at Low Temperatures. Appl. Catal. A 570 (2019) 42-50.

[32] N. Takada, Analysis and Interpretation of Acidic Nature of Aluminosilicates. Mol. Catal. 458 (2018) 116-126.

[33] O. Dulaurent, D. Bianchi, Adsorption Isobars for $\mathrm{CO}$ on a $\mathrm{Pt} / \mathrm{Al}_{2} \mathrm{O}_{3}$ Catalyst at High Temperatures using FTIR Spectroscopy: Isosteric Heat of Adsorption and Adsorption Model. Appl. Catal. A 196 (2000) 271-280.

[34] D. Bianchi, A Contribution to the Experimental Microkinetic Approach of Gas/Solid Heterogeneous Catalysis: Measurement of the Individual Heats of Adsorption of Coadsorbed Species by Using the AEIR Method. Catalysts 8 (2018) 265-285.

[35] S. Derrouiche, D. Bianchi, Heats of Adsorption Using Temperature Programmed Adsorption Equilibrium: Application to the Adsorption of $\mathrm{CO}$ on $\mathrm{Cu} / \mathrm{Al}_{2} \mathrm{O}_{3}$ and $\mathrm{H}_{2}$ on $\mathrm{Pt} / \mathrm{Al}_{2} \mathrm{O}_{3}$. Langmuir 20 (2004) 4489-4497.

[36] N. Kumar, A. Bansal, G.S. Sarma, R.K. Rawal, Chemometrics Tools Used in Analytical Chemistry: An Overview. Talanta 123 (2014) 186-199.

[37] F. Giraud, C. Geantet, N. Guilhaume, S. Loridant, S. Gros, L. Porcheron, M. Kanniche, D. Bianchi, Experimental Microkinetic Approach of De-NOx by $\mathrm{NH}_{3}$ on $\mathrm{V}_{2} \mathrm{O}_{5} / \mathrm{WO}_{3} / \mathrm{TiO}_{2}$ Catalysts. 3. Impact of Superficial $\mathrm{WO}_{\mathrm{z}}$ and $\mathrm{V}_{\mathrm{x}} \mathrm{O}_{\mathrm{y}} / \mathrm{WO}_{\mathrm{z}}$ Groups on the Heats of Adsorption of Adsorbed $\mathrm{NH}_{3}$ Species. J. Phys. Chem. C 119 (2015) 15401-15413. 
[38] F. Giraud, C. Geantet, N. Guilhaume, S. Loridant, S. Gros, L. Porcheron, M. Kanniche, D. Bianchi, Experimental Microkinetic Approach of De-NOx by $\mathrm{NH}_{3}$ on $\mathrm{V}_{2} \mathrm{O}_{5} / \mathrm{WO}_{3} / \mathrm{TiO}_{2}$ Catalysts. 2. Impact of Superficial Sulfate and/or $\mathrm{V}_{\mathrm{x}} \mathrm{O}_{\mathrm{y}}$ Groups on the Heats of Adsorption of Adsorbed $\mathrm{NH}_{3}$ Species. J. Phys. Chem. C 118 (2014) 15677-15692.

[39] T. Chafik, O. Dulaurent, J.L. Gass, D. Bianchi, Heat of Adsorption of Carbon Monoxide on a $\mathrm{Pt} / \mathrm{Rh} / \mathrm{CeO}_{2} / \mathrm{Al}_{2} \mathrm{O}_{3}$ Three-Way Catalyst Using in-Situ Infrared Spectroscopy at High Temperatures. J. Catal. 79 (1998), 1503-1514.

[40] F. Giraud, C. Geantet, N. Guilhaume, S. Loridant, S. Gros, L. Porcheron, M. Kanniche,

D. Bianchi, Experimental Microkinetic Approach of De-NOx by $\mathrm{NH}_{3}$ on $\mathrm{V}_{2} \mathrm{O}_{5} / \mathrm{WO}_{3} / \mathrm{TiO}_{2}$ Catalysts. 6. $\mathrm{NH}_{3}-\mathrm{H}_{2} \mathrm{O}$ Coadsorption on $\mathrm{TiO}_{2}$ Based Solids and Competitive Temkin Model. J. Phys. Chem. C 122 (2018) 24634-24651.

[41] G. Ramis, G. Busca, C. Cristiani, L. Lietti, P. Forzatti, F Bregani, Characterization of Tungsta-Titania Catalysts. Langmuir 8 (1992) 1744-1749.

[42] L. Lietti, J. Svachula, P. Forzatti, G. Busca, G. Ramis, F. Bregani, Surface and Catalytic Properties of Vanadia-Titania and Tungsta-Titania Systems in the Selective Catalytic Reduction of Nitrogen Oxides. Catal. Today 17 (1993) 131-140.

[43] P. Patrono, A. La Ginestra, G. Ramis, G. Busca, Conversion of I-butene over $\mathrm{WO}_{3}-\mathrm{TiO}_{2}$ Catalysts. Appl. Cata. A 107 (1994) 249-266.

[44] Onfroy, T.; Clet, G. Bukallah, S. B, Visser, T. Houalla, M. Acidity of Titania-supported Tungsten or Niobium Oxide Catalysts Correlation with Catalytic Activity. Appl. Catal. A. 2006, 298, 80-87.

[45] T. Onfroy, V. Lebarbier, G. Clet, M. Houalla, Quantitative Relationship Between the Nature of Surface Species and the Catalytic Activity of Tungsten Oxides Supported on Crystallized Titania. J. Mol. Catal. A 318 (2010) 1-7.

[46] T. Onfroy, G. Clet, M. Houalla, Acidity, Surface Structure, and Catalytic Performance of WOx Supported on Monoclinic Zirconia. J. Phys. Chem. B 109 (2005) 3345-3354.

[47] G. Centi, S. Perathoner, The Role of Ammonia Adspecies on the Pathways of Catalytic Transformation at Mixed Metal Oxide Surfaces. Catal. Rev.-Sci. Eng. 40 (1998) 175-208.

[48] M. Zhu, J-K. Lai, U. Tumuluri, Z. Wu, I.E. Wachs, Nature of Active Sites and Surface Intermediates during SCR of $\mathrm{NO}$ with $\mathrm{NH}_{3}$ by Supported $\mathrm{V}_{2} \mathrm{O}_{5}-\mathrm{WO}_{3} / \mathrm{TiO}_{2}$ Catalysts. J. Am. Chem. Soc. 139 (2017) 15624-15627.

[49] J. Lai, I.E. Wachs, A Perspective on the Selective Catalytic Reduction (SCR) of NO with $\mathrm{NH}_{3}$ by Supported $\mathrm{V}_{2} \mathrm{O}_{5}-\mathrm{WO}_{3} / \mathrm{TiO}_{2}$ Catalysts. ACS Catal. 8 (2018) 6537-6551. 
[50] L. Lietti, J.L. Alemany, P. Forzatti, G. Busca, G. Ramis, E. Giamello, F. Bregani, Reactivity of $\mathrm{V}_{2} \mathrm{O}_{5}-\mathrm{WO}_{3} / \mathrm{TiO}_{2}$ Catalysts in the Selective Catalytic Reduction of Nitric Oxide by Ammonia. Catal. Today, 29 (1996) 143-148.

[51] A. Marberger, D. Ferri, M. Elsener, O. Kröcher, The Significance of Lewis Acid Sites for the Selective Catalytic Reduction of Nitric Oxide on Vanadium-Based Catalysts. Angew. Chem., Int. Ed. 55 (2016) 11989-11994.

[52] G. Busca, L. Lietti, G. Ramis, F. Berti, Chemical and Mechanistic Aspects of the Selective Catalytic Reduction of NOx by Ammonia over Oxide Catalysts: A review. Appl. Catal. B. 18 (1998) 1-36.

[53] L. Lietti, I. Nova, S. Camurri, E. Tronconi, P. Forzatti. Dynamics of the SCR-DeNOx Reaction by the Transient-Response Method. AIChE J. 43 (1997) $2559-2570$.

[54] L. Lietti, I. Nova, E. Tronconi, P. Forzatti, Transient Kinetic Study of the SCR-DeNOx Reaction. Catal. Today, 45 (1998) 85-92.

[55] X. Xie, J. Lu, E. Hums, Q. Huang, Z. Lu, Study on the Deactivation of $\mathrm{V}_{2} \mathrm{O}_{5}-\mathrm{WO}_{3} / \mathrm{TiO}_{2}$ Selective Catalytic Reduction Catalysts through Transient Kinetics. Energy Fuels 29 (2015) 3890-3896.

[56] L. Lietti, Reactivity of $\mathrm{V}_{2} \mathrm{O}_{5}-\mathrm{WO}_{3}-\mathrm{TiO}_{2}$ de- $\mathrm{NO}_{\mathrm{x}}$ Catalysts by Transient Methods. Appl. Catal. B 10 (1996) 281-297.

[57] U. De-La-Torre, B. Pereda-Ayo, M.A. Gutiérrez-Ortiz, J.A. González-Marcos, J.R. González-Velasco, Steady-state $\mathrm{NH}_{3}-\mathrm{SCR}$ Global Model and Kinetic Parameter Estimation for NOx Removal in Diesel Engine Exhaust Aftertreatment with $\mathrm{Cu} / \mathrm{Chabazite}$. Catal. Today296 (2017) 95-104.

[58] I.C.U. Odenbrand, A. Bahamonde, P. Avila, J. Blanco, Kinetic Study of the Selective Reduction of Nitric Oxide over Vanadia-Tungsta-Titania/Sepiolite Catalyst. Appl. Catal. B 5 (1994) 117-131.

[59] R. Willi, B. Roduit, R.A. Koeppel, A. Wokaun, A. Baiker, Selective Reduction of NO by $\mathrm{NH}_{3}$ over Vanadia-Based Commercial Catalyst: Parametric sensitivity and Kinetic Modelling. Chem. Eng. Sci. 51 (1996) 2897-2902.

[60] M. Koebel, M. Elsener, Selective Catalytic Reduction of NO over Commercial DeNOxcatalysts: Experimental Determination of Kinetic and Thermodynamic Parameters. Chem. Eng. Sci. 53 (1998) 657-669.

[61] I. Nova, L. Lietti, E. Tronconi, P. Forzatti, Dynamics of SCR Reaction over a $\mathrm{TiO}_{2-}$ Supported Vanadia-Tungsta Commercial Catalyst. Catal. Today 60 (2000) 73-82. 
[62] R. Willi, R.A. Köppel, A. Baiker, High-Performance Aerogel DeNOx Catalyst: Catalytic Behavior and Kinetic Modeling. Ind. Eng. Chem. Res. 36 (1997) 3013-3018.

[63] F. Giraud, J. Couble, C. Geantet, N. Guilhaume, S. Loridant, S. Gros, L. Porcheron, M. Kanniche, D. Bianchi, Experimental Microkinetic Approach of De-NOx by $\mathrm{NH}_{3}$ on $\mathrm{V}_{2} \mathrm{O}_{5} / \mathrm{WO}_{3} / \mathrm{TiO}_{2}$ Catalysts. 5. Impacts of the $\mathrm{NH}_{3}-\mathrm{H}_{2} \mathrm{O}$ Coadsorption on the Coverage of Sulfated $\mathrm{TiO}_{2}-$ Based Solids. J. Phys. Chem. C 122 (2018) 24619-24633. 
Click here to access/download Supplementary Interactive Plot Data (CSV) SI-Catal-Today-2020-R1.doc 


\section{UNIVERSITE CLAUDE BERNARD - LYON I}

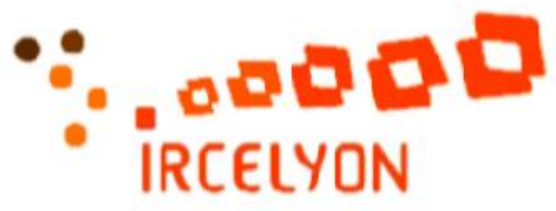

D. Bianchi

Emeritus Professor

to

Professor J.J. Spivey

Editor in Chief of Catalysis Today
INSTTIUT DE RECHERCHE SUR LA CATALYSE ET L'ENVIRONNEMENT DE LYON

CNRS - Université Claude Bernard LYON I

Unité Mixte de Recherche 5256

43, boulevard du 11 novembre 1918

69622 VILLEURBANNE CEDEX, France

Tél. : 0472431419

Télécopie : 0472448114

E-mail : daniel.bianchi@ircelyon.univ-lyon1.fr

Dear Prof. J.J. Spivey

Please find enclosed the revised version of the article submitted to Catalysis Today as contribution to the special issue for the $60^{\text {th }}$ anniversary of IRC/IRCELYON: "Individual amounts of Lewis and Brønsted acid sites on metal oxides from $\mathrm{NH}_{3}$ adsorption equilibrium: case of $\mathrm{TiO}_{2}$ based solids"

We have considered some comments of the two reviewers to improve the manuscript. Particularly, according to the comments of R2 we have significantly shorten the abstract ( -5 lines) and the introduction section (- 28 lines). The order of the references has been modified (removing one reference). However, considering one of the comments of R1 we have inserted 15 lines and a new reference (32) in the revised introduction.

R2 suggests discussing the location of the acidic sites according to the composition of the solids. As explained in the responses this was partially done in previous works using Raman and FTIR spectroscopy and literature data (i.e. $\mathrm{WO}_{\mathrm{x}}$ and $\mathrm{VO}_{\mathrm{y}}$ groups contribute to the $\mathrm{NH}_{3}$ adsorption over $\mathrm{WO}_{3} / \mathrm{TiO}_{2}$ and $\mathrm{V}_{2} \mathrm{O}_{5} / \mathrm{WO}_{3} / \mathrm{TiO}_{2}$ ). We have inserted different sentences on this point in particular taking into account literature data on the active sites of $\mathrm{V}_{2} \mathrm{O}_{5}-\mathrm{WO}_{3}-\mathrm{TiO}_{2}$ catalysts and the present measurements. A detailed description of the location of the acid sites according to the solid composition can be the topic of the future works.

The comments of R1 are mainly relevant of a scientific debate and not of the evaluation of the present work. They concern the validity, the interests and the originalities of the AEIR and TPAE methods used in the study to quantify the individual amounts of LAS and BAS. This has been done in previous works (first article on the AEIR method in 1998 ref (39)). Particularly R1 proposes a comparison with the IRMS-TPD method in operando mode which was cited in the manuscript. This explains that we provide detailed responses taking into account the references cited by R1. We show how it is tricky using IRMS-TPD as compared to AEIR and TPAE. However, this debate cannot be inserted in the present manuscript except (a) the 15 lines in the new introduction section on a specific application of the IRMS-TPD for the quantification of LAS and BAS and (b) the modification of Figure S1 in line with comments on the impact of the readsorption during TPD.

All the modifications are in red in a copy.

We thank the two reviewers for their contributions to the improvement of the manuscript.

Best regards,

D. Bianchi 


\section{Declaration of interests}

$\square$ The authors declare that they have no known competing financial interests or personal relationships that could have appeared to influence the work reported in this paper.

$\square$ The authors declare the following financial interests/personal relationships which may be considered as potential competing interests:

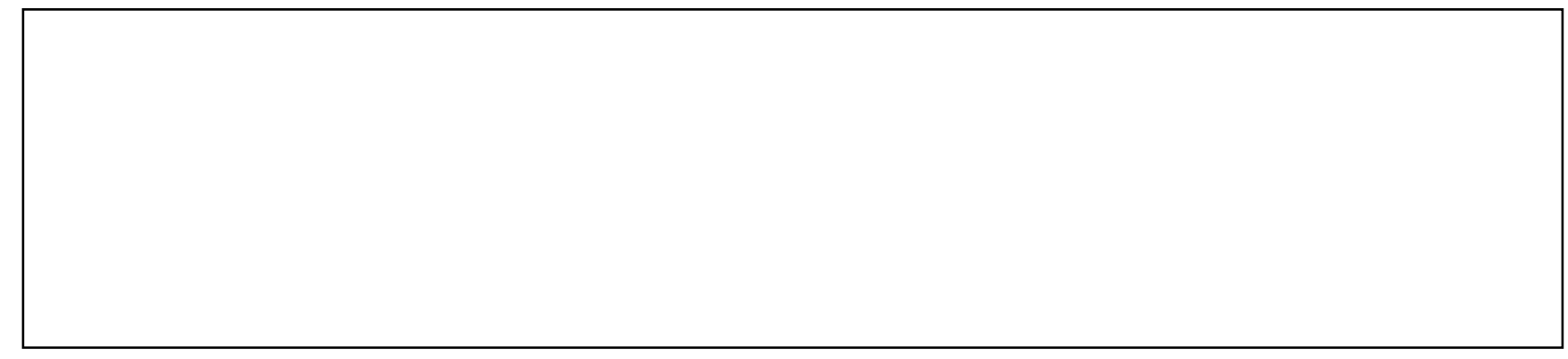

